CAHIER DE RECHERCHE \#1211E

WORKING PAPER \#1211E

Département de science économique

Department of Economics

Faculté des sciences sociales

Université d’Ottawa

Faculty of Social Sciences

University of Ottawa

\title{
Carbon Tax Salience and Gasoline Demand
}

\author{
Nicholas Rivers $^{*}$ and Brandon Schaufele ${ }^{\dagger}$
}

August 2012

\footnotetext{
* Graduate School of Public and International Affairs, University of Ottawa, 120 University, Social Sciences Building, Ottawa, Ontario, K1N 6N5; Email: nicholas.rivers@uottawa.ca.

${ }^{\dagger}$ Department of Economics, University of Ottawa, 120 University, Social Sciences Building, Ottawa, Ontario, Canada, K1N 6N5; Email: brandon.schaufele@uottawa.ca.
} 


\begin{abstract}
We demonstrate that the carbon tax imposed by the Canadian province of British Columbia, a unique carbon pricing policy that comprehensively applies to all fossil fuels, caused a decline in short-run gasoline demand that is significantly greater than would be expected from an equivalent increase in the market price of gasoline. That the carbon tax is more salient, or yields a larger change in demand than equivalent market price movements, is robust to a range of specifications including intuitively plausible and strong instrumental variables. Along with calculating the reduction in carbon dioxide emissions attributable to the tax, we discuss potential explanations for the differential consumer responses to the carbon tax relative to the marketdetermined price.
\end{abstract}

Key words: Carbon tax, tax salience, instrumental variables, environmental pricing, gasoline demand.

JEL Classification: C26, H23, H29, Q41, Q58.

\title{
Résumé
}

Nous démontrons que la taxe carbone imposée par la province canadienne de ColombieBritannique, une politique unique qui s'applique complètement à tous les combustibles fossiles, a causé une baisse de la demande d'essence qui est significativement plus élevé que prévu d'une augmentation équivalente de la le prix du marché de l'essence. Que la taxe carbone est plus saillant, ou donne une plus grande variation de la demande que leurs équivalents des mouvements des prix du marché, est robuste à une série de spécifications, y compris intuitivement plausibles et fort variables instrumentales. Ainsi que le calcul de la réduction des émissions de dioxyde de carbone attribuables à la taxe, nous discutons des explications possibles pour les réactions des consommateurs différentielles à la taxe carbone par rapport au prix déterminé par le marché..

Mots clés: Taxe carbone, saillance d'impôt, variables instrumentales, taxe environnementale, demande d'essence.

Classification JEL: C26, H23, H29, Q41, Q58. 


\section{INTRODUCTION}

On July 1st, 2008, the Canadian province of British Columbia (BC) enacted North America's first broad-based carbon tax designed to reduce greenhouse gas emissions. While several jurisdictions have implemented emission reduction programs, no other state or province has implemented a policy that is as ambitious and comprehensive as the BC policy, and no other North American greenhouse gas control policy taxes households directly based on emissions. ${ }^{1}$ Media has both lauded the BC carbon tax as a major policy achievement and condemned it as a "nightmare" for industry and families.

While carbon taxes have been in place in various European countries since the 1990s, econometric analysis of their impact is limited, ${ }^{2}$ and there is minimal evidence on the effectiveness of similar programs in the North American context. Research on the implications of an actual carbon price is particularly important as several states and provinces are currently debating whether or not to introduce similar broad-based policies. ${ }^{3}$ By exploiting crossprovincial panel data variation, a range of robustness checks as well as intuitively appealing and

\footnotetext{
${ }^{1}$ The Regional Greenhouse Gas Initiative (RGGI) is a leading example of a US emission control program. A joint initiative of nine states - Connecticut, Delaware, Maine, Maryland, Massachusetts, New Hampshire, New York, Rhode Island, and Vermont - its objective is to develop a market-based program aimed at "reduc[ing] $\mathrm{CO}_{2}$ emissions from the power sector [by] 10 percent by 2018" (RGGI, 2012). Similarly, the Canadian provinces of Alberta and Quebec have enacted carbon pricing policies. Alberta effectively taxes large industrial emitters $\left(>100,000\right.$ tonnes) at $\$ 15$ per tonne of $\mathrm{CO}_{2}$, while Quebec has a carbon tax on natural gas, coal and petroleum equal to $\$ 3$ per tonne $\mathrm{CO}_{2}$.

${ }^{2}$ Anderson (2010) describes European carbon taxes, and provides some evidence on their effectiveness using a simulation model. Econometric research on carbon taxes includes Martin, de Preux and Wagner (2011) who examine the UK's Climate Change Levy and Enevoldson, Ryelund and Andersen (2007) who examine Scandanavian industrial carbon taxes. It is difficult to use the limited empirical evidence from these studies in other contexts because (1) European carbon taxes were often introduced as replacements for existing energy taxes, not as standalone taxes, (2) they include numerous exemptions and differences in rates across sectors (Bruvoll and Larsen, 2004; Sumner, Bird and Smith, 2009), and (3) there may be different preferences, culture, or geography in these countries compared to others.

${ }^{3}$ Most notable is the state of California which adopted a state-administered cap-and-trade system on October 20, 2011. California's emission trading market is expected to be the cornerstone of the larger Western Climate Initiative, a collaborative effort with four Canadian provinces to develop a North American greenhouse gas emissions trading program.
} 
strong instrumental variables, this study provides the first causal evidence of the effect of a carbon tax on the short-run gasoline decisions of North American households.

Throughout our analysis we concentrate on the saliency of the BC carbon tax. Tax saliency refers to the hypothesis that tax-induced price changes generate distinct demand responses when compared with equivalent market-determined price movements. An emerging literature delves into this hypothesis (see Chetty, Looney and Kroft (2009), Finkelstein (2009), Congdon, Kling and Mullainathan (2009) and Goldin and Homonoff (2010)). This paper, in particular, can be viewed as an extension of Davis and Killian (2010) and Li, Linn and Muehlegger (2012), research which examines responses to excise taxes relative to price changes induced by supply shocks in the gasoline market. By evaluating a situation where a carbon tax actually exists however, this study makes an important contribution to this growing literature. To the best of our knowledge, ours is the first empirical investigation into the saliency of environmental taxation. Carbon taxes differ from excise or other consumption taxes in that, by imposing a disincentive on fossil fuel consumption, they are explicitly designed to reduce environmental externalities. Even though excise and sales taxes reduce gasoline demand in the short-run, they are not overtly designed to correct environmental externalities. Revenues from gasoline taxes, for example, are frequently earmarked for road infrastructure, projects which lower the long-run costs of driving. Concentrating on carbon pricing permits us to identify the relative saliency of a carbon tax compared with the underlying market price of gasoline when the unambiguous purpose of the policy is to reduce gasoline demand.

Our main result is that the $\mathrm{BC}$ carbon tax generated demand response that is 4.9 times larger than is attributable to an equivalent change in the carbon tax-exclusive price. In our preferred model, a five cent increase in the market price of gasoline yields a $2.2 \%$ reduction in 
the number of litres of gasoline consumed in the short-run, while a five cent increase in the carbon tax, a level approximately equal to a carbon price of $\$ 25$ per tonne, generates a $10.6 \%$ short-run reduction in gasoline demand. These results lead us to claim that the carbon tax is more salient than market-determined price changes: carbon taxes produce larger demand responses than tax-exclusive price increases. Due to the robustness and consistency of our estimates across a range of specifications including models that incorporate intuitively appealing and strong instrumental variables, we feel that our results can be interpreted as causal. We believe that it was BC's carbon tax that caused the decline in provincial gasoline demand. We also use our econometric results to construct counterfactual scenarios in order to calculate the change in gasoline-related emissions stemming from the carbon tax. We find that the BC policy reduced carbon dioxide emissions by more than 3 million tonnes. Of this total, $79.1 \%$, or 2.4 million tonnes, is due to the additional saliency of the carbon tax - i.e., it is an environmental bonus that would not have been achieved if individuals responded to carbon taxes in the same way as to identical changes in gasoline prices caused by other factors.

Our results are in line with Li, Linn and Muehlegger (2012) who find that consumers are more responsive to changes in gasoline excise taxes than to tax-exclusive prices. In particular, Li, Linn and Muehlegger estimate a tax saliency ratio (i.e., the mean consumer response to an increase in gasoline taxes divided by an equivalent increase in market prices) equal to 8.1 , a value that is within the range of our estimates. Although in a different context, our results also complement Finkelstein (2009) and Chetty, Looney and Kroft (2009) who suggest that consumers exhibit more elastic demand response if prices increase due to a highly visible tax than if prices increase for some other reason. Finkelstein shows that the demand curve for driving becomes more inelastic when tolls are charged electronically as compared to manual 
collection. Chetty, Looney and Kroft use experimental evidence to demonstrate that making a sales tax visible increases demand responsiveness. Yet it is not obvious that the retail gasoline market is sufficiently similar to electronic tolls or grocery store purchases to enable direct comparisons. Unlike most goods, gasoline prices are advertised as tax-inclusive. Both excise and sales taxes are included in stated rates, so buyers pay exactly the price that they see on signs and at the pumps (i.e., there is no risk of making mathematical errors between the instant consumers decide to buy fuel and the point where they must pay for the purchase).

The remainder of this paper contains five sections. Section two describes the design of the BC carbon tax policy. Section three presents our data and empirical methodology. The main results are in section four. Section five discusses the results including potential explanations for the added saliency of the carbon, calculations of the reduction of carbon dioxide emitted and possibly confounding policies that are coincident with the carbon tax. Section six concludes.

\section{DESIGN OF THE BC CARBON TAX}

The announcement that $\mathrm{BC}$ was introducing a carbon tax came as a surprise to the vast majority of residents (Harrison, 2012). The province's Finance Minister formally revealed the revenue-neutral carbon tax in her February 2008 budget speech. By July $1^{\text {st }}, 2008$, BC became the first jurisdiction in North America to have a significant carbon tax on all fossil fuels purchased within its borders. ${ }^{4}$ It was only during the second half of 2007 that the government began to hint that environmental pricing was possible. Even then, there was no public acknowledgement that carbon taxes were a prospective policy option until a speech late in

\footnotetext{
${ }^{4}$ The carbon tax applies to all emissions that result from the burning of fossil fuels. These account for $77 \%$ of total provincial emissions. The remaining $23 \%$ is not due to the combustion of fossil fuels, but includes: $10 \%$ from nonenergy agriculture and landfills, $9 \%$ from fugitive emissions, and $4 \%$ from non-combustion industrial process emissions (BC Ministry of Finance, 2012a).
} 
October 2007. ${ }^{5}$ Early reactions to the carbon tax were positive and polls showed that a majority of voters supported the policy (Harrison, 2012). Residents appear to have understood the impetus for the tax and accepted that it was a well-designed policy.

There are two prominent features of the BC carbon tax design. First, it was implemented gradually. The tax came into effect on July $1^{\text {st }}, 2008$. Initially set at $\$ 10$ per tonne carbon dioxide equivalent $\left(\mathrm{tCO}_{2} \mathrm{e}\right)$, the tax increased by $\$ 5 \mathrm{tCO}_{2} \mathrm{e}$ each July $1^{\text {st }}$ until 2012 , when it reached its current level of $\$ 30 \mathrm{tCO}_{2} \mathrm{e}$. The $\$ 10 \mathrm{tCO}_{2} \mathrm{e}$ tax implied a 2.34 cent increase in the price of a litre of gasoline. At $\$ 30 \mathrm{tCO}_{2} \mathrm{e}$, this represents an increase in the price of gasoline equivalent to 6.67 cents per litre. ${ }^{6}$ Table 1 presents the progression of the carbon tax in $\mathrm{tCO}_{2} \mathrm{e}$ and cents per litre of gasoline. Gradually increasing the tax was intended to minimize potential adjustment costs associated with the tax shift.

The $\mathrm{BC}$ carbon tax was also designed to be revenue-neutral. Revenue-neutrality meant returning all carbon tax revenues to residents via adjustments to personal and corporate taxes as well as lump-sum transfers. Several components of the personal and corporate tax schedule were adjusted to offset the revenues generated by the carbon tax. These changes are illustrated in Table 1. First, the BC government lowered rate of tax on the bottom two personal income tax brackets. For a household earning a nominal income of $\$ 100,000$, Table 1 shows that the average provincial tax rate was reduced from $8.74 \%$ in 2007 to $8.02 \%$ in 2008 . Two lump-sum

\footnotetext{
${ }^{5}$ Academic economists may have actually played an important role in marshalling support for this policy. Soon after the October speech, the Finance Minister received a letter written by David Green (Green, 2007), a professor at the University of British Columbia (currently the chair of the Department of Economics). Professor Green collected the signatures of 70 economics professors at BC's four major research universities, each who supported his letter calling on the government to enact a revenue-neutral carbon tax in the upcoming budget (Harrison, 2007).

${ }^{6}$ When the carbon tax was first introduced, the projected per litre tax at $\$ 30 \mathrm{tCO}_{2} \mathrm{e}$ equalled 7.24 cents per litre. Starting in 2010, the per litre carbon taxes were revised downward to reflect the province's biofuel mandate. Biofuels such as ethanol and biodiesel are exempt from the tax.
} 
transfers were also included to protect low-income and rural households. ${ }^{7}$ Low income households receive quarterly rebates, which, for a family of four, equal approximately $\$ 300$ per year $^{8}$ and beginning in 2011, northern and rural homeowners received a further benefit of up to $\$ 200 .^{9}$ Finally, taxes on corporations and small businesses were reduced. BC has two corporate tax rates, a high and low income rate. High income firms are those that earn profits above the provincial business limit. In conjunction with the carbon tax, this limit was increased from $\$ 400,000$ to $\$ 500,000$ in 2010 . Following the introduction of the carbon tax, the BC government cut both corporate and small business taxes. The corporate income tax rate was reduced in three steps. It went from $12.0 \%$ to $11.0 \%$ in 2008 , from $11.0 \%$ to $10.5 \%$ in 2010 and was finally reduced to $10.0 \%$ in 2011 . Similarly, Table 1 shows that the small business tax rate, which is applied to profits up to the provincial business limit, was cut by $1.0 \%$ in both 2008 and 2009 .

The revenue-neutrality of the carbon tax yields several benefits. First, it likely increased public acceptability for the policy. Since residents' tax burden did not increase, government was able to promote the policy as a "tax shift" rather than a tax increase. Second, by cutting personal and corporate income taxes (yet still keeping total government revenues constant), the policy minimizes the negative economic impacts of taxation and lowers the marginal cost of public funds. Extensive analysis of environmental tax shifts indicates that, in some cases, economic

\footnotetext{
${ }^{7}$ In addition to the tax shifts, all BC residents received a one-time "Climate Action Dividend". This was a payment of $\$ 100$ to every resident in the province in 2008.

${ }^{8}$ These payments started in 2008. Initially in a two parent household, each adult received a transfer of $\$ 100$ plus the household received an additional $\$ 30$ for each dependent. Transfers for single parent households equalled $\$ 100$ for the adult and first child as well as $\$ 30$ for each additional dependent. In 2009 and 2010, these transfers were increased to $\$ 105.00$ and $\$ 31.50$ for adults and dependents respectively and transfer amounts were further increased in 2011 to $\$ 115.50$ and $\$ 34.50$. Finally, in conjunction with the increasing low income transfer levels, the low income threshold, originally set at $\$ 30,000$ for singles and $\$ 35,000$ for married or single parent households, was increased in accordance with inflation.

${ }^{9}$ The northern and rural homeowner benefit was designed to offset perceived geographical inequity associated with the carbon tax. However, Peet and Harrison (2012) state that northern and rural residents actually have shorter commutes and pay lower gasoline prices than urban residents.
} 
activity might even increase as a result (Goulder, 1995). As a final point, revenue-neutrality acts as a commitment mechanism for the government, particularly as the carbon tax was implemented as the economy entered a recession. Once personal and corporate taxes had been reduced, the BC government needed the revenues generated by the carbon tax which equalled $\$ 741$ million in 2011 (BC Ministry of Finance, 2011). Discussions on delaying the scheduled increases had to be weighed against deficits and reduced social program spending.

The revenue-neutrality of the $\mathrm{BC}$ carbon tax design also provides a potential identification strategy. By construction, increases in the carbon tax are inversely related to personal and corporate tax revenue. This unique feature of the policy allows us to formulate economically sensible instrumental variables described in the empirical methodology section.

While our analysis focuses on the BC carbon tax, we also include - but do not emphasize - the much smaller Quebec carbon tax in our data and analysis. Quebec introduced a carbon tax in October 2007. The stated goal of the tax is to raise revenue to pursue environmental projects, in contrast to the $\mathrm{BC}$ tax which is aimed at discouraging fossil fuel combustion. Quebec's goal is to annually raise $\$ 100$ million from the tax; as a result, the tax rate is adjusted each year based on projected fossil fuel consumption. In practice the tax rate has remained relatively constant at about $\$ 3 \mathrm{tCO}_{2} \mathrm{e}$ since it was introduced.

\section{EMPIRICAL METHODOLOGY}

\subsection{Data $^{10}$}

Our empirical analysis requires a dataset assembled from several sources. Statistics Canada (2012) collects aggregate monthly data on litres of premium, mid-grade and regular

\footnotetext{
${ }^{10}$ Data and code written in $\mathrm{R}$ for all of the empirical models will be made available on the authors' websites.
} 
gasoline sold within each Canadian province. ${ }^{11}$ As in Small and Van Dender (2007), aggregate provincial sales are divided by the population proxied by the number of individuals aged 15 years or older yielding a variable on a per-adult basis. Price and excise tax information is retrieved from Kent Marketing Services Limited (2012). All prices and taxes are inflationadjusted using monthly, province-specific consumer price indices. The retail price in each province's largest urban centre proxies for the price for the entire province - while a high degree of price correlation within provinces exists, this may mask some intra-provincial heterogeneity. Notwithstanding, interprovincial variation is notably greater than within province deviations largely due to differential tax levels. Appendix Table A1 presents summary statistics for the monthly gasoline consumption and tax-inclusive prices by province. Additional data needed for controls, robustness checks and instrumental variable models such as after-tax income, share of small and compact car sales and income tax rates and revenues are from several sources including Statistics Canada (2012), DesRosiers Automotive Consultants Inc. (2012) and the BC Ministry of Finance (2012b). Our period analysis is January 1990 through December 2011 but we perform checks on shorter subsets of this timeframe. Regressions are run on both a monthly and annual basis, yet our preferred models use monthly data. The monthly dataset contains 2580 province-month observations. The annual dataset, which is generated by aggregating per capita litres consumed over the year and taking a simple per litre averages for prices and taxes, has 216 observations. Annual models supplement our preferred monthly specifications as several control variables are only available on a yearly basis.

\footnotetext{
${ }^{11}$ For the province of Nova Scotia, data do not start until March 1992. Data are unavailable for the province New Brunswick until November 1992.
} 
Figure 1 illustrates several key features of the data. In Panel A of Figure 1, a time series of the monthly per capita gasoline demand is plotted for BC. ${ }^{12}$ The introduction of the carbon tax on July 1, 2008 is shown by the vertical line. Also shown are simple linear time trends for the period from January 1, 2000 until the introduction of the tax, and for the period following the introduction of the tax. The figure suggests a break in the gasoline demand trend when the tax was introduced, which is not present in other provinces. This plot offers suggestive evidence that the carbon tax did reduce gasoline demand. Panel B of Figure 1 displays the average annual tax-inclusive per litre price of gasoline for Canada's four most populous provinces. Since 2004, the highest per litre prices in Canada are found in BC. We would expect the price gap between $\mathrm{BC}$ and the rest of the country to grow as the scheduled carbon tax increases were enacted. Yet, it is difficult to visually distinguish a wedge between provinces. Indeed, the gap between BC, Ontario and Quebec has appears to have shrunk. Further, although the degree of interprovincial price correlation is high, gas prices do vary across the country. As mentioned, these differences reflect differential gasoline taxes, but also distinct transportation costs and fluctuations in provincial supply conditions. Lastly, it should be emphasized that a five cent increase in the price of gasoline, roughly equal to $\$ 25 \mathrm{tCO}_{2} \mathrm{e}$, is well within one standard deviation for all provinces.

\subsection{Model}

This research has two primary goals. First, we want to explain the variation in per capita gasoline consumption as a function of market prices and carbon taxes. Second, we seek to

\footnotetext{
${ }^{12}$ In this figure, the gasoline demand series has been seasonally adjusted by regressing monthly demand on year dummies and month*province dummies, allowing a distinct seasonal pattern in each province (as suggested by the data). For each province, the month dummies are then subtracted from the gasoline demand series.
} 
determine whether equivalent price and tax changes yield distinct demand responses. In order to evaluate these objectives, we use the approach of Li, Linn and Muehlegger (2012) and decompose the retail price of gasoline, the price that consumers see at pumps, into two components: a carbon tax-exclusive price and a carbon price. More precisely, we specify the following linear equation:

$$
y_{i t}=\alpha p_{i t}+\beta \tau_{i t}+\mathbf{X}_{i t} \boldsymbol{\theta}+\delta_{i}+\gamma_{t}+\varepsilon_{i t}
$$

where $y_{i t}$ is the per capita number of litres of gasoline consumed in province $i$ during period $t$ (months or years), $p_{i t}$ is the carbon tax-exclusive inflation-adjusted price of gasoline in province $i$ during period $t,{ }^{13} \tau_{i t}$ represents the inflation-adjusted carbon tax in province $i$ during period $t, \delta_{i}$ is province-specific fixed effect that captures geographically constant and time invariant unobservable characteristics, while $\gamma_{t}$ is a time fixed effect reflecting either month-years or years (depending on the resolution of the data) and captures time specific unobserved factors that may influence gasoline demand. $\mathbf{X}_{i t}$ represents other potentially relevant variables that vary at the province-year level. These include provincial after-tax income and the share of small and compact cars in the vehicle stock. Finally, $\varepsilon_{i t}$ is a province and period specific error term. Robustness checks using first-differenced models are also presented.

Our preferred specification is a log-linear model as this provides a straightforward interpretation of the effects of the carbon tax (Yatchew and No, 2001). The BC carbon tax is published in cents per litre, thus coefficients, which approximately reflect semi-elasticities or percent change in gasoline demand for a given level of tax, have intuitive appeal. ${ }^{14}$ Finally,

\footnotetext{
${ }^{13}$ Prices include both provincial and federal excise taxes.

${ }^{14}$ Throughout this paper, all semi-elasticities are calculated as the exponent of the coefficient minus one (e.g., $\left.e^{\beta}-1\right)$; however, estimates which are small in absolute value can be interpreted directly as a semi-elasticity as the difference is negligible.
} 
while equation (1) separates prices, taxes and geographical fixed effects, many of our models interact the provincial dummies with prices and taxes respectively (e.g., $\alpha \cdot p_{i t} \cdot \delta_{i}+\beta \cdot \tau_{i t} \cdot \delta_{i}$ ). We find that demand for gasoline in $\mathrm{BC}$ is more elastic than for the country as a whole and this influences our ability to make inferences with respect to the saliency of prices and taxes. Interactions enable us to identify the price and tax responses separately for the province of $\mathrm{BC}$.

\subsection{Identification}

Our identification strategy includes three components. First, we exploit the panel structure of the data. Next, instrumental variables are introduced. Finally, we perform a series of robustness checks which involve including potentially omitted variables and focusing on particular sub-samples. These checks attempt to eliminate other explanations for our results. Only after our key parameters are shown to be robust across a wide-range of specifications do we interpret the results as causal.

The primary method of identification is derived from the panel structure of the data. Time-invariant, region-specific characteristics such as geography are accommodated by the provincial fixed effects. Time-varying but non-province-specific unobservables (e.g., trade policy) are captured by the time fixed effects. Any remaining province-time varying factors are grouped into the error term or included in the model. Provided gasoline prices and carbon taxes are uncorrelated with the error term, least squares yields unbiased and consistent estimates of the price $(\alpha)$ and the carbon tax coefficients $(\beta)$.

There are persuasive reasons to believe that both the market price of gasoline and the carbon tax are exogenous in our empirical models. The gasoline market is generally considered competitive: wholesale gasoline price is determined in continental gasoline markets, and gasoline 
retailing generally involves small margins. This argument is supported by Marion and Muehlegger (2011) who demonstrate that under normal market conditions any change in excise taxes is fully reflected in final prices - i.e., any change in taxes is "fully and immediately passed on to consumers" (1202). ${ }^{15}$ Similarly, the BC carbon tax was introduced within a short period of time, caught most residents by surprise, comprehensively covers all fossil fuels and the policy's sole objective is to reduce greenhouse gas emissions (i.e., not to influence other outcomes), so it is unlikely to be confounded. Considering this, both the BC carbon tax and the market price of gasoline are probably exogenous variables. Our preferred models are therefore parsimonious and use least squares to identify the parameters.

Nonetheless, while convincing arguments support the exogeneity of gasoline prices and the carbon tax, we want to eliminate doubt regarding potential simultaneity or omitted variable bias. We do this by exploiting instrumental variables. Conceivable channels exist through which bias may arise. For instance, recent construction of bicycle-only lanes in some Canadian cities in a time period coincident with BC's carbon tax may have caused some drivers to forego vehicle ownership just as the tax was introduced. This decision reduces congestion and lowers the cost of driving for the remaining motorists. Lowering the cost of driving then may encourage some households to drive more. Thus the net effect of the bike lanes on driving may lead us to either under- or over-state the true impact of the carbon tax (since our models do not include a bike lane variable). Along the same lines, Davis and Killian (2010) claim that macroeconomic factors such as 2008 recession influenced gasoline prices. Inasmuch as the recession has dissimilar consequences across provinces bias could arise. Although these effects are likely second-order, we use instrumental variable models estimated via two-stage least squares to

\footnotetext{
${ }^{15}$ This implies that firms are price-takers and supply is perfectly elastic.
} 
supplement our core results, since well-designed instruments allow us to consistently estimate key parameters in the presence of omitted variables.

As either or both the market price of gasoline or the carbon tax could be endogenous, instruments are needed for each. Aggregate provincial personal and corporate income tax revenues instrument for the carbon tax and provincial gasoline excise taxes instrument for gasoline prices. Monthly data on excise taxes are available. So, we estimate monthly models where the price is the potentially problematic variable. Income tax information is just available annually. Accordingly, models for which the carbon tax is potentially endogenous are only estimated using annual data. Three annual formulations are investigated: a model where the price of gasoline is potentially problematic, a model where the carbon tax is potentially problematic and a model where both variables are deemed to be potentially endogenous.

Two-stage least squares enables the estimation of unbiased coefficients under specific conditions. Appropriate instruments must (Murray, 2006): i) not be economically relevant in our model of interest (second-stage); ii) be relevant or correlated with our potentially problematic variable; and, iii) be valid or uncorrelated with the error term in our model of interest (1). Effort is devoted to ensuring that our set of instruments is appropriate, strong and valid. Economic arguments are required to assert the exogeneity of our instruments, whereas relevance and validity can, in some cases, be tested. The second criterion for appropriate instruments states that the instruments must be relevant or "strong". Weak instruments do not eliminate (and may exacerbate) the bias of least squares. By applying two-stage least squares, we assess relevance by inspecting the excluded instruments in the first-stage model. Explicitly, we specify a null hypothesis stating that the excluded instruments are irrelevant in the first-stage and then calculate an F-statistic. Large F-statistics reassure us that our instruments are strong. The third criterion, 
point iii), is referred to in this paper as instrument validity not exogeneity. This is to distinguish it from the economic arguments needed to back the instruments' exclusion, or exogeneity, in the second-stage. Instrument validity implies that the excluded instruments are uncorrelated with the error term in the second-stage model. We approach validity via two channels. First, instrument validity is tested using a Sargan test on over-identifying restrictions in models that contain more instruments than endogenous variables. The null hypothesis is that all of the instruments are valid. A rejection of the null means that some of the instruments are invalid, but the test provides no information on which if any instruments are valid. For two of our models, we calculate Sargan statistics. We also present two models that are exactly identified - i.e., there are exactly as many instruments as troublesome variables. In these cases, economic arguments are used to assuage concerns about instrument validity. There is an additional step with respect to evaluating the quality of our instrumental variable regressions. Wu-Hausman tests determine whether anything is gained by using two-stage least squares. Instrumental variable methods allow consistent estimation of coefficients when least squares is problematic. However, they trade-off efficiency in the form of larger standard errors for unbiasedness. Wu-Hausman statistics test whether the loss of efficiency is justified. Specifically, the null hypothesis of the Wu-Hausman states that both the least squares and instrumental variables coefficients are consistently estimated, but that the instrumental variables estimator is less efficient. A rejection of the null implies that only the instrumental variables coefficients are consistent. Of course, non-rejection implies that the least squares estimates are unbiased, consistent and more efficient than the comparable instrumental variable models. This test yields valuable information for when we select our preferred results. 
We are most concerned about bias due to the endogeneity of the price of gasoline. As such, we apply the approach of Davis and Killian (2010). The market price of gasoline is instrumented with provincial, inflation-adjusted excise taxes. Excise taxes comprise a significant share of the final price of gasoline, so the link between tax changes and price movements is obvious (i.e, excise taxes are a strong instrument for the price of gasoline). However, Davis and Killian argue that changes in tax legislation occur with a "considerable lag" (1197) and therefore any variation in tax rates are exogenous to short-run changes in gasoline demand. Marion and Muehlegger (2011) make a similar assertion in their analysis of the incidence of excise taxes. We assume this argument is reasonable and maintain it.

Next, there is a high probability that the carbon tax is exogenous. Still we exploit unique features of the policy design to formulate an instrumental variable strategy. Specifically, the revenue-neutrality of the carbon tax generates two potential instruments. Personal and corporate income taxes were both reduced in conjunction with the introduction of the policy. Therefore, aggregate provincial personal and corporate income tax revenue should be negatively correlated with the carbon tax. It is challenging to find plausible channels through which total provincial income tax revenues may be linked to per capita gasoline demand, especially as total expected government revenues remain constant (as described above, an explicit goal of the policy was to maintain revenue neutrality). So, even despite arguments in favour of the exogeneity of the carbon tax, we consider these instruments to be especially appealing.

Identifying our key parameters is of utmost importance, yet we are equally interested in testing the impact of the carbon pricing policy relative to equal changes in the price of gasoline. Formally we do this by constructing confidence intervals for our key coefficients and then checking whether these intervals overlap. Overlapping confidence intervals imply that we 
cannot reject a null hypothesis which states that a market-determined price elasticity is statistically identical to a carbon tax elasticity. Non-overlapping confidence intervals imply the opposite, that the null is rejected. In this latter case, we claim that the carbon tax is either more or less salient than the market-determined price of gasoline and that equivalent price changes produced distinct demand responses. Our models are estimated with both time and province fixed effects which accommodate many potential autocorrelation and heteroskedasticity concerns. Still, ensuring that our confidence intervals are correct is key. We do not want to inadvertently reject a hypothesis that is true, so care is put into finding appropriate standard errors. Several methods are examined including errors clustered on time and bootstrapped standard errors. Ultimately, our tables present heteroskedasticity and autocorrelation consistent (Newey-West) standard errors as these were generally found to be the largest and we sought consistency across Tables.

Finally, we perform a series of robustness checks. We include potentially important omitted variables such as after-tax income and the share of small and compact car sales by province. We also inspect distinct sub-samples and rule out storage and announcement effects as explanations for our findings.

\section{ECONOMETRIC RESULTS}

\subsection{Overview of Main Findings}

Three sets of results are presented. First, estimates from parsimonious least squares models are discussed. Results from instrumental variable models and robustness checks are then reviewed. Overall we find economically meaningful and statistically significant coefficients when we use monthly data. Regressions using annual data are less precise and often have 
confidence intervals that include zero. Point estimates from the annual models do buttress the monthly results however.

Figure 2 displays of our preferred model. The figure plots the coefficients from a regression of monthly gasoline consumption on the interactions of the carbon tax and market price of gasoline with the fixed effect for the province of BC (model (2) in Table 2). Also presented are the 50\% (the bold line) and 95\% (thin line) confidence intervals. Clearly, the carbon tax has a much larger impact on gasoline demand than do market prices. The point estimate on the carbon tax equals -0.0210 which, for a carbon tax of $\$ 25 \mathrm{tCO}_{2} \mathrm{e}$, implies a $10.6 \%$ decrease in gasoline demand. An equivalent increase in the market price of gasoline predicts a $2.2 \%$ reduction in demand (the coefficient equals -0.0043 ). Stated differently, the BC carbon tax generated a demand response that is 4.9 times greater than an equivalent increase in market prices.

Upon initial consideration, the sizeable difference between the elasticities for the carbon tax and price of gasoline may surprise. However, there is convincing corroborating evidence bolstering the external validity of the finding. Even though designed to be revenue-neutral, in actuality, the $\mathrm{BC}$ carbon tax has been revenue negative. The carbon tax has collected less revenue than the government initially forecast. Indeed, only $83 \%$ of the initially forecast revenues has come in, well-below the benchmark of revenue-neutrality and a deficit too large to ascribe to poor forecasting (BC Ministry of Finance, 2012b). Our main conclusion appears sound: the carbon tax causes a larger change in demand than equivalent changes in the market price.

Throughout the three sets of results, models estimated using monthly data have economically meaningful coefficients which are statistically significantly different from zero. 
Models estimated using annual data have economically meaningful coefficients, yet we cannot always reject the null that the estimates are distinct from zero. Coefficients from the instrumental variable models and robustness checks corroborate our main findings. Few statistically significant results are found for the instrumental variable models, but $\mathrm{Wu}$-Hausman tests indicate that the least squares coefficients are unbiased and are more efficient than the instrumental variables models. Likewise, estimates from the robustness checks support the general pattern found in the parsimonious least squares models.

\subsection{Least Squares Results}

Tables 2 and 3 present results from the least squares models. Table 2 displays the coefficient estimates and standard errors for four models. Table 3 shows the confidence intervals and interprets the estimates. Model indices (e.g., (1), (2), etc.) refer to exactly the same model Table 2 and Table 3. Results using monthly data are in (1) and (2), while estimates using annual data in (3) and (4). All specifications include provincial and time fixed effects and have loglinear formulations.

Table 2 shows that the coefficient on the market price of gasoline in (1) is statistically insignificant and equal to -0.0014 . The coefficient of the carbon tax in this model is statistically significantly different from zero and equals -0.0457 . Weighing these against parameters in (2) where prices and taxes are interacted with provincial fixed effects, several notable differences surface. First, BC residents are more sensitive to changes in the price of gasoline compared with the country as a whole. The absolute value of the estimate for price in (2) is four times larger than in (1). Similarly, comparing the coefficients on the carbon tax between the two models reduces the initial estimate from -0.0457 to -0.0210 , likely because in (1) the carbon tax was 
capturing BC's added responsiveness to gasoline prices. Results from the annual models in (3) and (4) show a similar pattern. BC residents are more responsive to increases in gasoline prices than the rest of Canada, with a statistically insignificant coefficient of -0.0034 in (4) compared with an insignificant -0.0002 in (3). The carbon tax estimates have a parallel configuration, although statistically significantly different from zero, with coefficients equal to -0.0631 and -0.0320 in (3) and (4) respectively.

Table 3 interprets the coefficients from in Table 2. In (2) for instance, a five cent increase in the price of gasoline leads to a $2.2 \%$ reduction in the demand for gasoline in BC. Barla et al. (2009) estimate short-run price elasticities for Canadian gasoline demand of roughly -0.1 . With an average gasoline price of approximately 60 cents per litre during the period of the study, Barla et al.'s elasticities imply a 5 cent increase in gasoline price reduces short run demand by about $0.8 \%$. These estimates can be compared to (1) and (3), which show a five cent increase in the price of gasoline reduces demand by $0.7 \%$ and $0.1 \%$ respectively. In general, the results for the responsiveness of gasoline demand to changes in price are consistent with the literature. Unlike previous studies however, we are interested in the relative responsiveness of demand to carbon taxes and prices. Based on the confidence intervals presented in Table 3 , we are able to reject the null hypothesis of identical consumer responses to prices and carbon taxes for the monthly models in (1) and (2). A similar claim cannot be made for (3) and (4), where the confidence intervals overlap. Still, inspection of the bottom row of Table 3, which shows the ratio of the carbon tax to price semi-elasticities at a carbon price of $\$ 25 \mathrm{tCO}_{2} \mathrm{e}$, highlights that the carbon tax has a larger effect than the price of gasoline in every case (i.e., the ratio is greater than one). 
The estimates that we focus on are in (2). We find that in the short-run a $\$ 25 \mathrm{tCO}_{2} \mathrm{e}$ tax yields a $10.6 \%$ reduction in the demand for gasoline, an effect that is 4.9 times greater than would be expected from an equivalent increase in the market price of gasoline. There are three reasons why this is our preferred model: i) the coefficients are precisely estimated, ii) the point estimates are in the neighbourhood of the majority of the other specifications, and iii) the model is simple and parsimonious. In section 5.2, this is the model used to calculate the counterfactual scenarios and determine the reduction in tonnes $\mathrm{CO}_{2} \mathrm{e}$ emitted.

\subsection{Instrumental Variables Results}

Table 4 presents the coefficients from the instrumental variable models. Also displayed are the diagnostics on instrument relevance and validity. The dependent variable in (1) is monthly per capita gasoline consumption. (2), (3) and (4) have annual per capita gasoline consumption as the dependent variable. Table 5 interprets these coefficients and presents the confidence intervals. As above, models correspond exactly between the two tables.

In (1), the monthly market price of gasoline is instrumented with provincial excise tax. The F-statistic on the excluded instruments in the first-stage is 566.25 indicating that, as expected, excise taxes strongly predict gasoline prices. Testing whether the instrument is correlated with the second-stage error term is not possible as the model is exactly identified. Examining the coefficients, the point estimates for the price of gasoline and carbon tax equal -0.0057 and -0.0134 , respectively. These are comparable with (2) in Table 2 . The instrumental variables models are less precisely estimated and, as a consequence, we cannot reject the null hypothesis that the effect of the carbon tax is statistically different from zero. However, nonrejection of the null hypothesis in the $\mathrm{Wu}-$ Hausman test indicates that the least squares estimates, 
those from (2) in Table 2, are unbiased, consistent and efficient - i.e., the difference between the least squares and instrumental variables estimates is purely random. Both the consistency of the coefficient estimates and the Wu-Hausman statistic substantially bolster the credibility of our preferred model.

(2), (3) and (4) in Table 4 use annual data and are best compared with the rightmost column in Table 2. We will discuss (2) and (3) before turning attention to (4). The potentially problematic variable in (2) is the market price of gasoline which is instrumented by the annual average excise tax. The first-stage F-statistic for this model is large and equal to 29.33. The carbon tax is considered endogenous in (3). Provincial personal and corporate income tax revenues are used as instruments. The F-statistic on the excluded instruments in this case equals 19.23 indicating that the instruments are relevant. Moreover, in (3), there are more instruments than endogenous variables, so a Sargan test is formulated. The null hypothesis for the Sargan test is that all of the instruments are valid. That we cannot reject the null offers confidence that our instruments are valid in this formulation. Although neither is statistically significantly different from zero, the coefficients on the carbon tax variable in (2) and (3) are remarkably similar. The point estimate in (2) is -0.0361 , whereas the value in (3) is -0.0356 . The parameter estimates for the market price of gasoline are comparable, but the similarity is not as pronounced as for the carbon tax. Table 4 shows that the point estimate in (2), where price is considered endogenous, is -0.0013 and, in (3), where the carbon tax is the endogenous variable, it equals -0.0036. Neither of these is significantly different from zero. The corresponding estimate from Table 2 is -0.0034 . Next, as in (1), we are not able to reject the null hypothesis of the WuHausman test for either (2) or (3), indicating that the least squares estimates are unbiased, consistent and more efficient than the instrumental variables results. 
Finally, (4) in Table 4 considers both the market price of gasoline and the carbon tax as potentially problematic. These results colour our previous instrumental variable findings. The point estimates for the coefficients resemble the other models equalling -0.0015 and -0.0278 for gasoline prices and the carbon tax. Yet, unlike the previous results, the null of the Sargan and $\mathrm{Wu}$-Hausman tests must be rejected, suggesting that this specification may be problematic. Further, the F-statistic on the excluded instruments is smaller than in the other formulations. The Angrist-Pischke multivariate F-statistic (Angrist and Pischke, 2009) for excise taxes equals 15.95, while it is 6.55 for personal and corporate taxes. Despite the rejection the Sargan test, the point estimates confirm the main conclusion and our preferred model uses monthly data. Thus, while some concern is warranted when we consider both the price of gasoline and the carbon tax as potentially endogenous within the same model, the implications of the instrument invalidity appear to be minor.

The interpretation of the instrumental variable models is in Table 5. For (1), the model that uses monthly data and considers the price of gasoline to be endogenous, a five cent increase in the price of gasoline then yields a $2.9 \%$ reduction in litres consumed. This should be compared with the $2.2 \%$ decrease from (2) in Table 3 . The same five cent increase in the carbon tax reduces demand by $6.7 \%$ in the instrumental variable model compared with $10.6 \%$ using the least squares coefficients. However, in contrast with the results from the least squares models, it is not possible to reject the hypothesis that the carbon tax generated a statistically significantly different demand response when compared to the market price of gasoline. Even though we cannot statistically claim that the carbon tax is more salient than gasoline prices, we do not believe that jeopardizes our main interpretation. At risk of belabouring the point, instrumental variable estimates have inflated standard errors relative to least squares models and we cannot 
reject the null in the $\mathrm{Wu}-$ Hausman test. Therefore, particularly when confidence intervals are being constructed, it is more appropriate to rely on the least squares models. Nonetheless, the inability to uphold the finding in Table 3 must be noted. Using the point estimates and a $\$ 25 \mathrm{tCO}_{2} \mathrm{e}$ carbon tax, the coefficients from (1) imply that the carbon tax generates a demand response that is 2.4 times greater than would be expected from an equivalent increase in the market price of gasoline.

As Table 5 illustrates we are also unable to claim that the market price of gasoline and the carbon tax yielded distinct behaviour responses for instrumental variable models (2) and (3). Still, at $\$ 25 \mathrm{tCO}_{2} \mathrm{e}$, the carbon tax reduces gasoline demand by 28.3 and 10.0 times more than equivalent price movements in (2) and (3), respectively. For both models, a five cent increase in the carbon tax leads to an $18 \%$ reduction in gasoline demand. An equivalent increase in market prices only reduces gasoline consumption by $0.7 \%$ in (2) but by $1.8 \%$ in (3). For (4), a statistically significant difference between the price and tax coefficients is found as the confidence intervals do not overlap. A five cent increase in prices and carbon taxes correspond to declines in gasoline consumption of $0.8 \%$ and $14.1 \%$, implying the demand is 18.8 times more responsive to the carbon tax.

\subsection{Robustness Checks}

Table 6 displays results from a range of robustness checks. Ten models are presented. Across all specifications, the coefficients for both the market price of gasoline and the carbon tax are consistent with and corroborate the results from the least squares and instrumental variables models. Taken together, these specifications reinforce the main conclusion that the carbon tax 
policy generated a larger demand response than would be expected from an equivalent increase in the market price of gasoline.

After-tax income is included in both the monthly and annual models in (1) and (2) of Table 6. Data on income are only available on an annual basis for 1990-2010. For (1) then, monthly income is imputed by dividing by twelve on a year-over-year basis. It is important that after-tax rather than gross income is used: due to the tax shift (revenue-neutrality) personal income taxes were reduced in conjunction with the introduction of a carbon tax, so individuals actually had more money to allocate between consumption and savings. ${ }^{16}$ Including income into the models produces almost no change in the estimated response to the market price of gasoline. Both the monthly and annual coefficients are similar to those in Table 2. Demand responses to the carbon tax are tempered by the inclusion of income, but only by a small amount. The response to the carbon tax relative to the price of gasoline is still 3.5 times larger in the monthly model and 6.1 times greater in the annual model. When we re-estimate (1) and (2) using firstdifferences rather than levels, similar results materialize. (3) and (4) show the first-differenced results and demonstrate that our conclusions are not sensitive to the use of levels. Based on these four models, income effects do not appear to drive the larger consumer response to the carbon tax. All key parameters are roughly consistent to the inclusion or exclusion of income and not unduly influenced by specification.

A range of chronological effects may also potentially impact our results. First, if a structural break in the demand for gasoline occurred prior to the carbon tax policy, the coefficients may reflect a coincident change in preferences. Even though Hughes, Knittel and Sperling (2008) demonstrated that the short-run demand for gasoline has become more inelastic

\footnotetext{
${ }^{16}$ After-tax income refers to income after federal and provincial income taxes only. It does not account for other taxes such as sales or excise.
} 
in recent decades, it is possible that demand in $\mathrm{BC}$ has become more elastic and that it is this change in preferences that the carbon tax coefficient is capturing. In (5), we limit the monthly sample to January 2007 through December 2011 and find no appreciable difference in the coefficients. The behavioural response to the carbon tax is still 4.1 times larger at the mean using the restricted sample. Still, other temporary, temporally contingent effects around the date of the carbon tax introduction could influence our estimates. For example, estimates may be measuring an announcement effect and not a distinct behavioural response to equivalent price changes. There are two main ways that an announcement effect may manifest itself: i) individuals may reduce their consumption in the month or two months following the introduction of the tax because they are more attentive to their level of gasoline consumption or ii) individuals may shift their consumption to earlier months or purchase and then store fuel in the months preceding the carbon tax. With respect to storage, Borenstein, Bushnell and Lewis (2004) and Marion and Muehlegger (2011) state that the capacity gasoline storage is extremely limited. Selected purchasers may be able to store some fuel, but capacity generally does not extend for more than a month. Along the same lines, we must distinguish between temporary and permanent announcement effects. An announcement effect associated with the carbon tax that causes a permanent change in behaviour should be interpreted differently when compared with an announcement effect that causes households to alter their driving patterns for a brief period before reverting to old habits. The former situation emphasizes the prospective saliency or information content of the carbon pricing policy, whereas the latter may be considered a fad and the true effect is not persistent. In (6) and (7), the months of June and July and May through August are, respectively, dropped from the dataset. If an announcement effect is present, either due to a storage decision or temporary change in behaviour, the coefficient on the carbon tax 
should be smaller and closer to the estimate for the price of gasoline. We see the opposite. Even with the limited sample, estimates for both variables remain consistent. Month-year time fixed effects are included in all of the models, so perhaps this result is not surprising. All the same, this enables us to conclude that the saliency of the carbon tax is not driven by an announcement effect, rescheduling of travel plans or storage.

Three final robustness checks are completed. In (8), provincial and month fixed effects are interacted and a trend is added. With this model, we eliminate the possibility of provincespecific seasonality as an explanation for the added saliency of the carbon tax. Again the estimated coefficients are in the expected neighbourhood. Finally, (9) and (10) include the percentage of small and compact car sales out of all new car and all new vehicle sales as potentially omitted variables. The coefficients on these variables have the appropriate sign and are significant, but have little influence on the point estimates for gasoline prices and the carbon tax. In section 5.3, we discuss several other non-testable explanations for our results. However, the robustness of our key coefficients across a range of specifications and sub-samples strengthens our conclusion.

\section{Discussion}

\subsection{Carbon Tax Saliency}

Rationalizing the saliency of the carbon tax is challenging within conventional consumer theory. Equivalent price changes for the same good, whether motivated by policy or supply shocks, should yield identical changes in quantity demanded. Yet, this is not what we find. Instead, our results contribute to a growing literature that observes that people respond differently to tax- and market-induced price changes. 
In general, behavioural economics has been applied to explain the saliency phenomenon. Finkelstein (2009), Chetty, Looney and Kroft (2009) and Goldin and Homonoff (2010) focus on individual irrationality in the form of inattentiveness or cognitive costs as a motive for their results. Consumers misoptimize or apply rules-of-thumb and these errors manifest themselves as empirically distinct responses to taxes and prices.

Li, Linn and Muehlegger (2012) find a larger response to excise taxes relative to prices in the gasoline market. They rationalize this as an announcement effect or change in expectations spurred by the lower volatility of the tax-induced price changes. Neither of these hypotheses is satisfying when we consider the BC carbon tax. First, all carbon tax changes occur on July $1^{\text {st }}$, so any announcement effect would be observed in July and August. Robustness checks established that our conclusions are not driven by short-term announcement effects. Similarly, we identify a short-run response to price fluctuations in the gasoline market. Once the carbon tax is announced, its nominal value does not change for twelve months. Market prices fluctuate over the course of the year however. Inasmuch as consumers are able to reallocate their travel across time, this would cause them to be more responsive to market prices not less. For example, assume that a family is planning a trip and has flexibility with respect to the date of departure. If gas prices are high today and the family's expectation is that prices are mean reverting, they will delay their trip until the subsequent month. This implies that market prices had a larger effect on household decisions when compared to the carbon tax. Quite simply, individual irrationality, expectations and announcement effects do not adequately explain the results we identify.

Congdon, Kling and Mullainathan (2009) describe how many of the insights from behavioural economics have yet to be explored within the tax policy literature. In particular, they highlight non-standard preferences as an overlooked area. Non-standard preferences refers 
to the notion that individuals may be "other-regarding" or not "perfectly self-interested" or may use "reference points" (377). The welfare of others and, in this case, the environment may enter directly into the utility function.

We deem non-standard preferences as a prospective explanation for the saliency of the carbon tax. In particular, a form of non-standard preference which we refer to as resentment of free-ridership may have existed. Consider a situation where driving involves congestion costs and there are two types of people: environmentally and non-environmentally conscious drivers. Assume that an environmentally conscious driver wants to contribute to a public good (i.e., lower her carbon emissions) by reducing the amount that she drives. ${ }^{17}$ Without a price on carbon, one outcome of her decision to drive fewer kilometres is that it lowers the cost of driving for the non-environmentally conscious driver, enabling him to drive more. This is a form of leakage where actual emission reductions from the environmentally conscious driver are eliminated by increases in emissions from other drivers. Even if there are net positive environmental benefits, the environmentally conscious driver may be resentful of this leakage. This resentment may manifest itself as a disincentive to contribute to the public good. Ultimately, resentment of freeridership may cause the environmentally conscious driver to contribute less to the public good than if free-riding was not possible.

Imposition of a carbon tax eliminates the free-ridership problem and, as a consequence, any resentment of free-ridership. A carbon tax forces all drivers to pay an environmental cost for each litre of gasoline consumed. An environmentally conscious driver can therefore reduce her kilometres knowing that the non-environmentally conscious individual is paying the full environmental costs of his decision. As an addendum to this argument, it is worth noting that

\footnotetext{
${ }^{17}$ In return, the environmentally conscious driver may, for example, receive a warm glow (Andreoni, 1990).
} 
governments tend not to enact high profile policies such as carbon taxes without some mandate from the electorate. Insofar as resentment of free-ridership prevented environmentally conscious voters from contributing to an environmental public good, the policy may act as a form of coordinating mechanism or focal point, one that leverages non-standard preferences, inasmuch as it acts as a corrective tax. In other words, the mere fact that the policy was introduced is a signal that a sizeable share of $\mathrm{BC}$ residents supported some form of emission control policy.

Regardless of whether we attribute the saliency of the carbon tax to individual irrationality, announcement effects or non-standard preferences, there is strong evidence for the external validity of our findings. As mentioned, the carbon tax was designed to be revenueneutral but is, in fact, revenue-negative. The carbon tax will collect $\$ 510$ million less than expected over its first four years. ${ }^{18}$ This is a $16.7 \%$ shortfall, an amount too large to blame on forecasting error. The carbon tax does seem to have generated a larger demand response than anticipated.

\subsection{Reductions in Quantity of Gasoline Demanded and Carbon Emissions}

Three scenarios are constructed to determine the reduction in litres demanded and emitted tonnes of $\mathrm{CO}_{2} \mathrm{e}$ attributable to the $\mathrm{BC}$ carbon tax. ${ }^{19}$ We use the coefficients from our preferred model throughout. Scenario one is a baseline counterfactual which represents the situation had no carbon policy been introduced. Scenario two represents a situation where it is assumed that the carbon tax has an elasticity of demand which is identical to the price of gasoline - i.e., it is

\footnotetext{
${ }^{18}$ This is an undiscounted sum of the difference between forecast and actual revenues over the first three years plus the difference between the initial forecast and updated forecast for the most recent fiscal year.

${ }^{19}$ Note that the BC carbon tax affects all fossil fuels consumed in the province, not just gasoline. However, our analysis is restricted to the impact of the carbon tax on gasoline sales.
} 
the "equivalent response" scenario. Lastly, scenario three is the "salient carbon tax" scenario and employs the model-predicted quantity demanded.

Figure 3 plots for 2007 through 2011 the annual average of monthly gasoline demand for the three scenarios. Scenario one reflects the (simulated) baseline counterfactual demand for gasoline. It charts the number of per capita litres gasoline consumed per month without any carbon price. Demand remains relatively stable with fewer litres demanded in 2008 than in 2011. Scenario two has a corresponding shape to scenario one; however, a growing wedge, reflecting the carbon taxes' increase from 2.3 cents per litre in 2008 to 5.6 cents per litre in 2011 , is apparent. Scenario two reflects a counterfactual where the carbon tax had the same influence as any other increase in the price of gasoline. Finally, scenario three shows the decrease in quantity of gasoline demanded that is the result of the differential response to the carbon tax. The elasticity of demand for the carbon tax is nearly five times larger than for market prices. Obviously, this translates into a larger decline in litres demanded which is exhibited in the figure. In 2011, predicted per capita demand per month is 10.5 litres lower in scenario three than in scenario one. In fact, demand in scenario three continues to trend downward even as scenarios one and two increase.

Figure 4 illustrates the province-wide, monthly reduction in $\mathrm{tCO}_{2} \mathrm{e}$ attributable to the carbon tax. For each scenario, predicted per capita monthly litres demanded are multiplied by population to obtain the aggregate monthly demand of gasoline for the entire province of $\mathrm{BC}$. Volume of fuel demanded is then converted into $\mathrm{tCO}_{2} \mathrm{e}$ to obtain the gross tonnes emitted under the three scenarios. ${ }^{20}$ Using scenario one as the baseline, we calculate the reduction in emissions

\footnotetext{
${ }^{20}$ Each litre of gasoline combusted generates $2.47 \mathrm{kgCO}_{2} \mathrm{e}$. This assumes that the energy content of gasoline is $35 \mathrm{MJ} / \mathrm{L}$, while the $\mathrm{CO} 2 \mathrm{e}$ content is $70.68 \mathrm{tCO}_{2} \mathrm{e} / \mathrm{TJ}$. Putting it together: $1 \mathrm{~L}=35 \mathrm{MJ} * 0.07068 \mathrm{~kg} \mathrm{CO}{ }_{2} \mathrm{e} / \mathrm{MJ}=$ $2.4738 \mathrm{kgCO}_{2} \mathrm{e}$. Note that the $\mathrm{BC}$ government uses a slightly different carbon content adjustment because of the
} 
from a situation where no carbon price policy is enacted. The dark bars depict the difference between scenarios one and two. This is the saved emissions had the carbon tax yielded the same demand response as conventional price increases. The lighter grey bars reflect the actual emission reduction. Over the first four years, the BC carbon tax reduced emissions by 3.04 $\mathrm{MtCO}_{2} \mathrm{e}$. The large majority (about $80 \%$ ) of this reduction is due to the saliency of the tax.

\subsection{Other Potential Explanations for the Results}

Two alternative explanations, cross-border shopping and contemporaneous vehicle efficiency policies, could also potentially explain our findings. Both are discussed in turn. We believe that neither is credible and think that there are good reasons to trust that it is the carbon tax that caused the change in consumer behaviour.

The first alternative explanation is that the carbon tax coefficient is actually capturing a cross-border shopping effect. Higher prices due to the carbon tax may have encouraged drivers to begin filling their gas tanks in neighbouring jurisdictions. We are unable to dismiss this explanation, yet believe that it is unlikely. Alberta is to the east of BC, while Washington State is to the south. Both jurisdictions have had lower gasoline prices than $\mathrm{BC}$ for many years, including a lengthy period prior to the introduction to the carbon tax (refer to Panel B in Figure 1). Further, over $95 \%$ of BC's population would need to drive more than two hours to reach the Alberta border, while crossing into Washington involves an international border. It is doubtful that a sizeable share of residents suddenly began cross-border shopping because of the carbon tax. Nonetheless, this is a potential alternative explanation for our findings.

exemption for the biofuel mandate that exists in the province. Our calculations effectively assume that over their lifecycle biofuels generate the same emissions as conventional gasoline. 
$\mathrm{BC}$ also increased funding for its accelerated vehicle retirement program, known as SCRAP-IT, in the two years following the introduction of the carbon tax (Antweiler and Gulati, 2011). Likewise it offered subsidies for hybrid vehicle purchases in the years preceding the tax (Chandra, Gulati and Kandlikar, 2010). Both policies can be considered coincident with the carbon tax. One concern is that these programs sufficiently altered the composition of the vehicle stock, increasing the average fuel economy and leading us to misattribute the reduction in gasoline demanded to the carbon tax. Several arguments lead us to believe this is unlikely. The main reason is the scope of the programs was too small. SCRAP-IT, a program which offered individuals incentives to purchase more fuel efficient cars $^{21}$ covered 18,000 vehicles over 2008 to 2011 period (Antweiler and Gulati, 2011). This is less than 1\% of the over 2 million passenger vehicles registered in the province (BC Statistics, 2011). ${ }^{22}$ Even if every vehicle that entered the SCRAP-IT program was removed from the road, the total litres of gasoline saved would account for only a small fraction of the decrease in gasoline demand. Besides, the majority of SCRAP-IT vehicles were replaced with newer cars and our robustness checks demonstrate that the carbon tax coefficient is not sensitive to small and compact car sales. Along the same lines, hybrid vehicles comprised only $1.1 \%$ of all vehicles sold in BC in 2006 and Chandra, Gulati and Kandlikar (2010) demonstrate that hybrid vehicles tend to replace other small or fuel efficient vehicles. So, the actual increase in fuel economy is small. On balance, these programs are simply too minor to jeopardize our main conclusions. As a final point, it is worth noting that $\mathrm{BC}$ residents historically tended to purchase vehicles that were already more fuel efficient than average (Chandra, Gulati and Kandlikar, 2010), implying that any accelerated

\footnotetext{
${ }^{21}$ Participants could also switch to public transit or receive a subsidy in order to purchase a bicycle (Antweiler and Gulati, 2011).

${ }^{22}$ There are also the more than 700,000 commercial vehicles registered in the province (BC Statistics, 2011).
} 
retirement or hybrid subsidy program would have less of an effect in BC than might be found in other provinces or states.

Finally, we emphasize that our results are limited to the short-run, so explanations based on a durable goods model of consumer behaviour are not appropriate. For example, while it is possible that risk averse consumers make different vehicle purchase decisions when faced with a fixed carbon price compared to a volatile gasoline price. Our analysis is based primarily on monthly data where very little turnover in vehicle stock is present. Additionally, in selected specifications, we control for characteristics of the vehicle stock without a substantive effect on coefficients.

\section{Conclusion}

This paper presents the first rigorous empirical evaluation of an actual carbon tax within a North American context. Through a wide-range of econometric specifications, we demonstrate that the carbon tax introduced by the Canadian province of $\mathrm{BC}$ is more salient than equivalent changes in price. A five cent increase in the carbon tax, all else constant, causes gasoline demand to decline by $10.6 \%$ whereas an identical five cent increase in the market price of gasoline leads to a $2.2 \%$ reduction in litres consumed. At $\$ 25 \mathrm{tCO}_{2} \mathrm{e}$, the carbon tax is 4.9 times more salient than the market price of gasoline. Finally, over the first four years of the policy, the $\mathrm{BC}$ carbon tax led to a total reduction in emissions of over 3 million $\mathrm{tCO}_{2} \mathrm{e}$ when compared with a counterfactual scenario of no tax.

To our knowledge, this is the first analysis of the saliency of environmental pricing. The results contribute to a prevailing shift to incorporate behavioural economics into tax and environmental policy. While current theory points to individual irrationality as an underlying 
mechanism for the saliency phenomenon, the discussion in this paper signals that individuals have may also have non-standard preferences - in this case with respect to environmental public goods. As the tax saliency literature matures, an improved understanding of how markets and policy interact within consumer utility functions will develop. We view this research as a contribution to both the behavioural economics of tax policy as well as providing rigorous empirical estimates for the demand elasticity of an actual carbon tax.

Our findings have several direct environmental policy implications. Most obvious is that individuals do not necessarily respond in the same way to tax increases as to supply shocks. Although our analysis is based on a single policy, the results should be taken into account by policy-makers who are considering introducing environmental taxes which affect gasoline prices. Indiscriminate use of gasoline elasticities may generate inaccurate forecasts of tax revenue and emissions. Our analysis also adds another wrinkle to the price uncertainty versus quantity uncertainty debate that has coloured discussions of tax versus cap-and-trade systems. In particular, our analysis suggests that environmental taxes that directly affect consumer prices result in a larger demand response than an equivalent supply shock. Depending on how consumers view allowance prices (as an environmental 'price' or as a supply shock) consumers may respond quite differently to equivalent prices in cap and trade and carbon tax policies, adding another dimension to the comparison of these instruments. 


\section{References}

Anderson, M.S., 2010. "Europe's Experience with Carbon-energy Taxation.” S.A.P.I.E.N.S., 3(2): $1-11$.

Andreoni, J. 1990. "Impure Altruism and Donations to Public Goods: A Theory of Warm-Glow Giving.” Economic Journal, 100(401): 464-477.

Angrist, J.D. and J-S Pischke. 2009. Mostly Harmless Econometrics: An Empiricist's Companion. Princeton University Press: Princeton. (Correction posted at:

www.mostlyharmlesseconometrics.com/2009/10/multivariate-first-stage-f-not/)

Antweiler, W. and S. Gulati. 2011. "An Analysis of British Columbia's SCRAP-IT Program: Emissions Savings, Participation, and Transportation Choice.” Paper presented at European Association of Environmental and Resource Economists' 18th Annual Conference, 29 June - 2 July 2011, Rome. (http://www.webmeets.com/EAERE/2011/m/viewpaper.asp?pid=1396.)

Barla, P., B. Lermonde, L.F. Miranda-Moreno and N. Boucher. 2009. "Traveled Distance, Stock and Fuel Efficiency of Private Vehicles in Canada: Price Elasticities and Rebound Effect." Transportation, 36: 389-402.

Borenstein, S., J. Bushnell and M. Lewis. 2004. "Market Power in the California Gasoline Market," Center for the Study of Energy Markets, working paper 132.

British Columbia Ministry of Finance. 2011. "Consolidated Revenue Fund Extracts." http://www.fin.gov.bc.ca/ocg/pa/10_11/PA_2011_CRF_Extracts.pdf, (last accessed June 15, 2012).

British Columbia Ministry of Finance. 2012a. "Myths and Facts about the Carbon Tax." http://www.fin.gov.bc.ca/tbs/tp/climate/A6.htm, (last accessed April 17, 2012).

British Columbia Ministry of Finance. 2012b. Budget and Fiscal Plan: 2012/13-2014/15. http://www.bcbudget.gov.bc.ca/2012/bfp/2012_Budget_Fiscal_Plan.pdf.

British Columbia Statistics. 2011. "Other Economic Statistics: Licenced Motor Vehicles." http://www.bcstats.gov.bc.ca/StatisticsBySubject/Economy/OtherEconomicStatistics.aspx. (Last accessed July 17, 2012).

Bruvoll, A. and B.M. Larsen. 2004. "Greenhouse Gas Emissions in Norway: Do Carbon Taxes Work?" Energy Policy, 32: 493-505.

Chandra, A., S. Gulati and M. Kandlikar. 2010. "Green Drivers or Free Riders? An Analysis of Tax Rebates for Hybrid Vehicles." Journal of Environmental Economics and Management, 60(2): 78-93. 
Chetty, R., A. Looney and K. Kroft. 2009. "Salience and Taxation: Theory and Evidence." American Economics Review, 99(4): 1145-1177.

Congdon, W.J., J.R. Kling and S. Mullainathan. 2009. "Behavioral Economics and Tax Policy," National Tax Journal, LXII(3): 375-386.

Davis, L.W. and L. Kilian. 2011. "Estimating the Effect of a Gasoline Tax on Carbon Emissions." Journal of Applied Econometrics, 26: 1187-1214.

DesRosiers Automotive Consultants Inc. 2012. Vehicle Sales. http://www.desrosiers.ca/index.html.

Enevoldsen, M.K., A.V. Ryelund and M.S. Andersen. 2007. "Decoupling of Industrial Energy Consumption and $\mathrm{CO}_{2}$-Emissions in Energy-intensive Industries in Scandinavia." Energy Economics, 29(4): 665-692.

Finkelstein, A. 2009. "E-ztax: Tax Salience and Tax Rates.” Quarterly Journal of Economics, 124(3): 969-1010.

Goldin, J. and T. Homonoff. 2010. "Smoke Gets in Your Eyes: Cigarette Tax Salience and Regressivity,” Working Papers (Princeton University. Industrial Relations Section), no. 561.

Goulder, L. 1995. "Environmental taxation and the double dividend: A reader's guide." International Tax and Public Finance, 2(2): 157-183.

Green, D. 2007. "Why 70 Economists Urge BC Carbon Tax. The Tyee, http://thetyee.ca/Views/2007/11/01/CarbonTax/, (last accessed April 17, 2012).

Harrison, K. 2012. "A Tale of Two Taxes: The Fate of Environmental Tax Reform in Canada." Review of Policy Research, 29(3): 383-407.

Hughes, J.E., C.R. Knittel and D. Sperling. 2008. "Evidence of a Shift in the Short-Run Price Elasticity of Gasoline Demand.” Energy Journal, 29(1): 93-114.

Kent Marketing Services. 2012. Petroleum Price Data.

http://www.kentmarketingservices.com/dnn/PetroleumPriceData.aspx.

Kruger, J., W.E. Oates and W.A. Pizer. 2007. "Decentralization in the EU Emissions Trading Scheme and Lessons for Global Policy." Review of Environmental Economics and Policy, 1(1): 112-133.

Li, S., J. Linn and E. Muehlegger. 2012. “Gasoline Taxes and Consumer Behaviour.” NBER working paper, no. 17891.

Marion, J. and E. Muehlegger. 2011. "Fuel Tax Incidence and Supply Conditions," Journal of Public Economics, 95: 1202-1212. 
Martin, R., L.B. de Preux and U.J. Wagner. 2011. "The Impacts of the Climate Change Levy on Manufacturing: Evidence from Microdata.” NBER working paper, no. 17446.

Murray, M.P. 2006. “Avoiding Invalid Instruments and Coping with Weak Instruments.” Journal of Economic Perspectives, 20(4): 111-132.

Peet, C. and K. Harrison. 2012. "Historical Legacies and Policy Reform: Diverse Regional Reactions to British Columbia's Carbon Tax.” Unpublished manuscript.

Regional Greenhouse Gas Initiative (RGGI). 2012. "Welcome.” www.rggi.org, (last accessed April 17, 2012).

Small, K.A. and K. Van Dender. 2007. "Fuel Efficiency and Motor Vehicle Travel: The Declining Rebound Effect." Energy Journal, 28(1): 25-51.

Statistics Canada. 2012. Cansim Database. http://www5.statcan.gc.ca/cansim/homeaccueil?lang=eng.

Sumner, J., L. Bird and H. Smith. December 2009. "Carbon Taxes: A Review of Experience and Policy Design Considerations.” National Renewable Energy Laboratory, Technical Report NREL/TP-6A2-47312.

Yatchew, A. and J.A. No. 2001. "Household Gasoline Demand in Canada." Econometrica, 69(6): 1697-1709. 


\section{Figures}
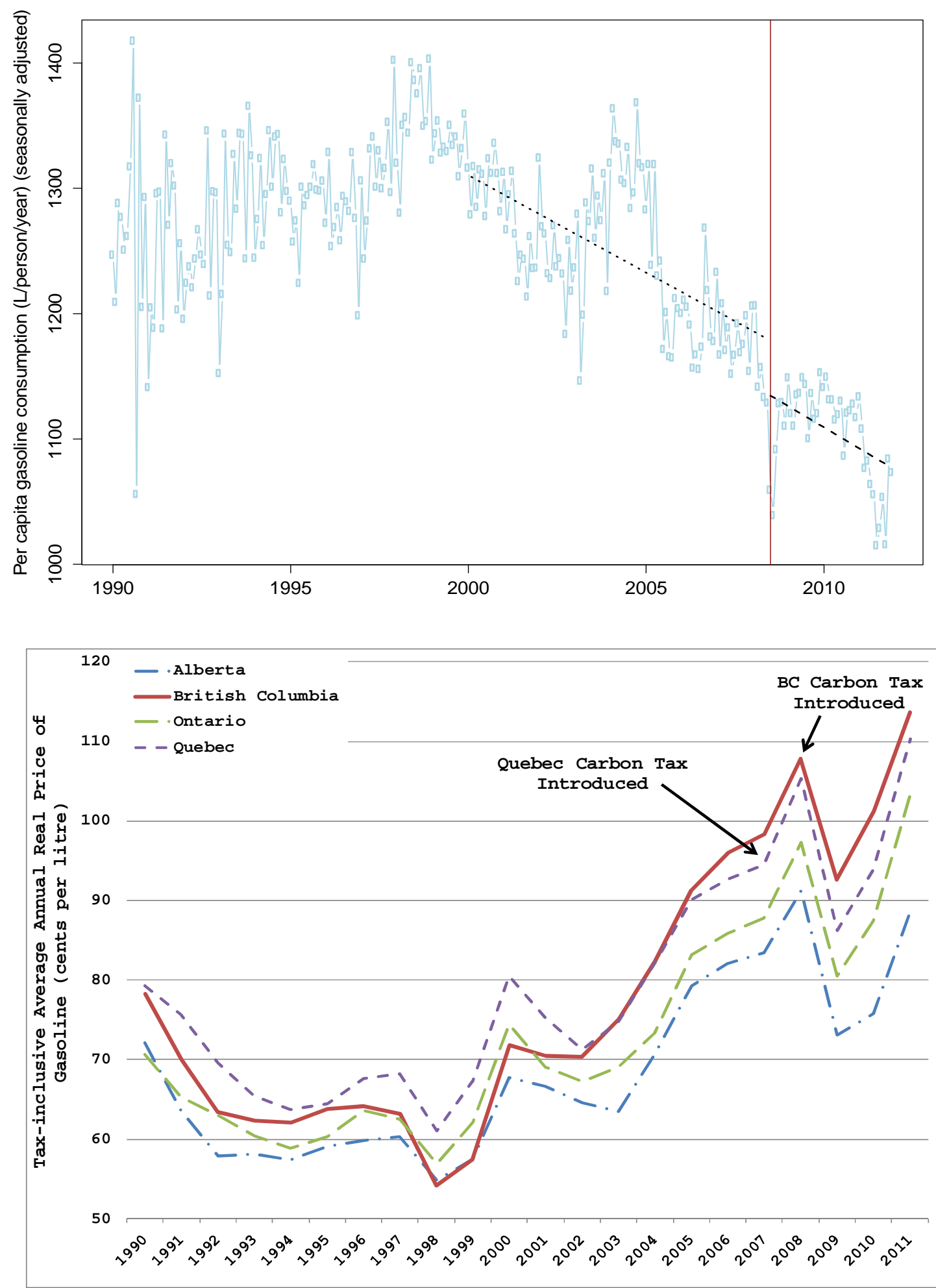

Figure 1: Average Monthly per Capita Consumption in British Columbia (Panel A) and Tax-inclusive Price of Gasoline for Canada's Four Largest Provinces (Panel B) 
Least Squares Estimates of the Effect of

Market Prices and Carbon Taxes on per Capita Gasoline Demand

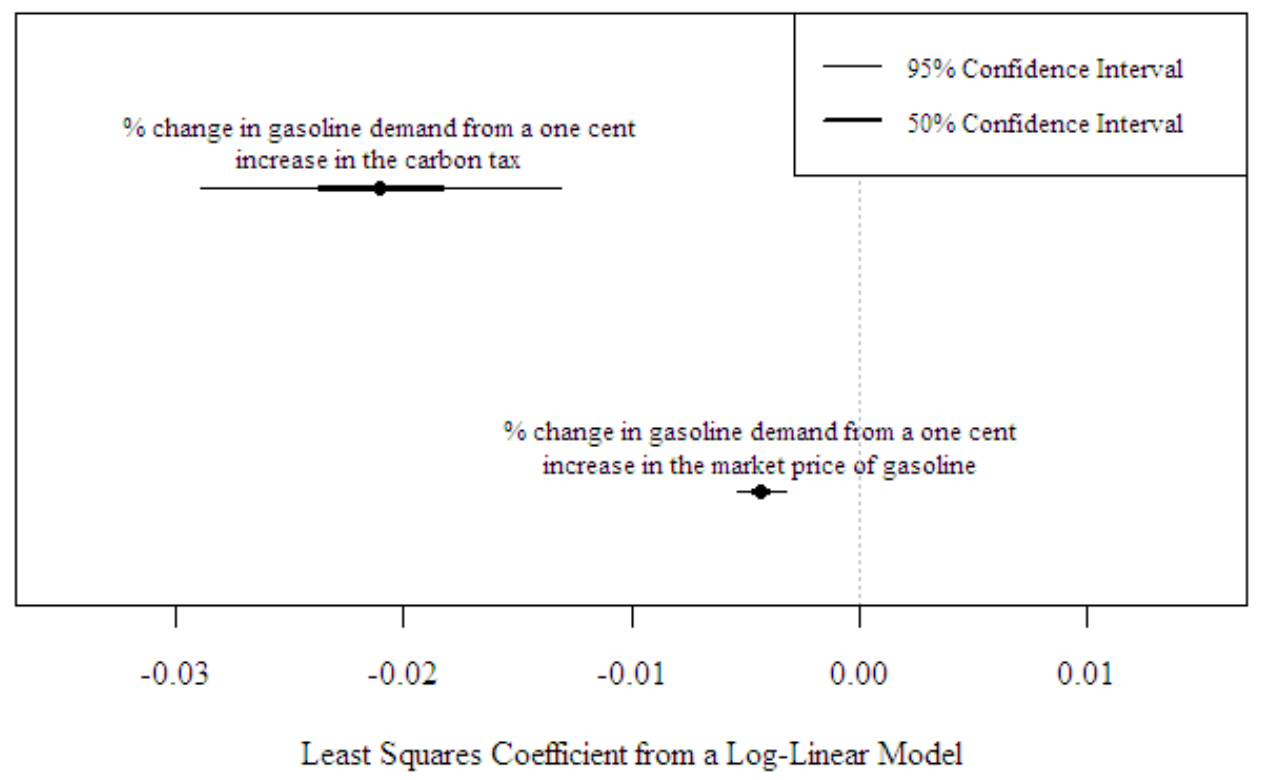

Figure 2: Effect of Gasoline Prices and Carbon Taxes on Gasoline Demand in BC: Point Estimates and Confidence Intervals 


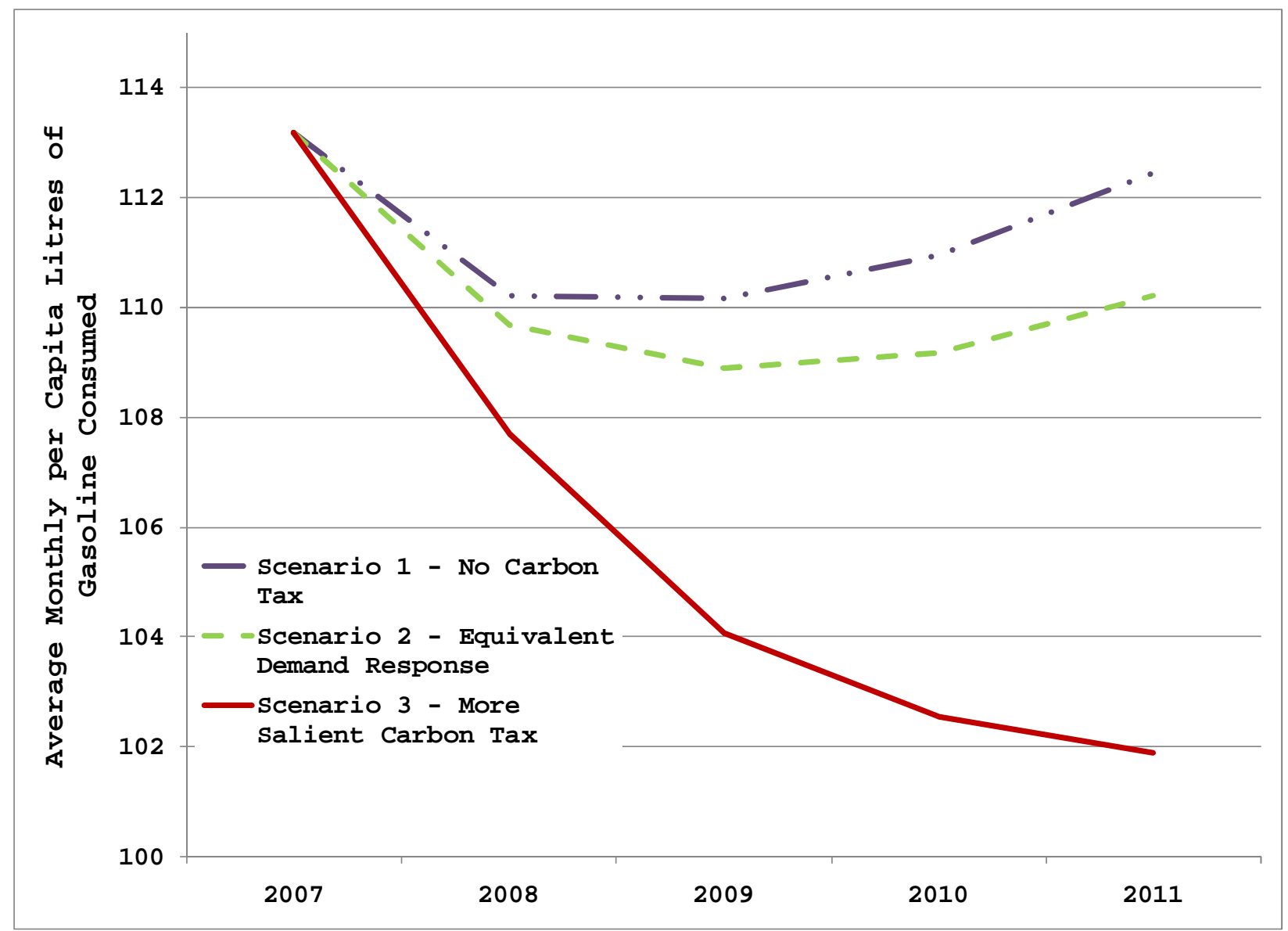

Figure 3: Average Monthly per Capita Consumption of Gasoline Consumed in British Columbia: Counterfactual Scenarios 


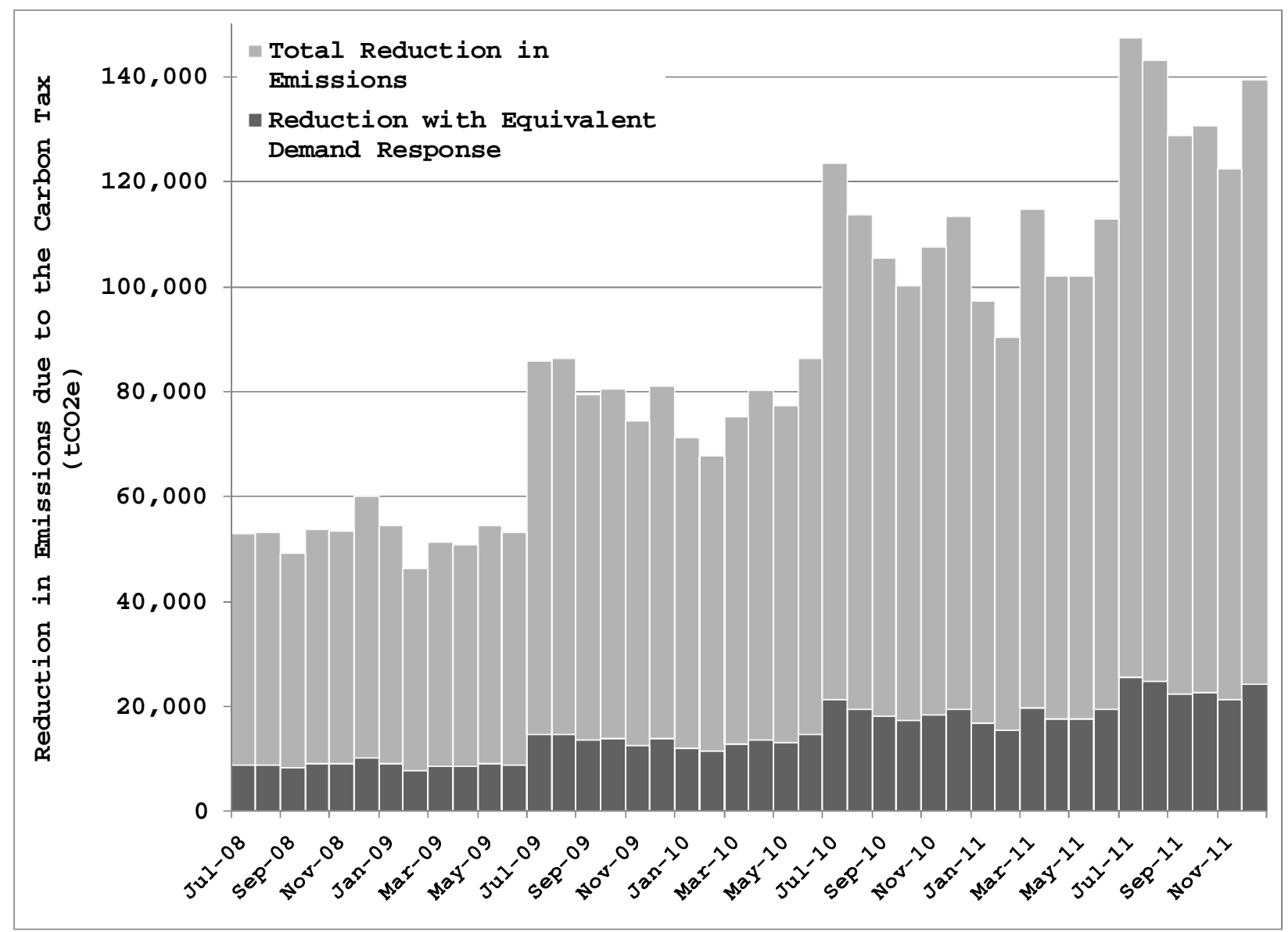

Figure 4: Reduction in Emissions Attributable to the Carbon Tax 


\section{Tables}

Table 1: Key Characteristics of the Revenue Neutrality of the BC Carbon Tax Design*

\begin{tabular}{lcccccc}
\hline \hline & $\begin{array}{c}\text { Carbon Tax } \\
\text { (\$/tonnes) }\end{array}$ & $\begin{array}{c}\text { Carbon Tax } \\
\text { (cents/litre) }\end{array}$ & $\begin{array}{c}\text { Provincial } \\
\text { Personal Income } \\
\text { Tax Rate on } \\
\mathbf{\$ 1 0 0 , 0 0 0}\end{array}$ & $\begin{array}{c}\text { Provincial } \\
\text { Business Limit }\end{array}$ & $\begin{array}{c}\text { Provincial } \\
\text { Corporate } \\
\text { Income Tax Rate } \\
\text { (high income) }\end{array}$ & $\begin{array}{c}\text { Provincial Small } \\
\text { Business Tax } \\
\text { Rate } \\
\text { (low income) }\end{array}$ \\
\hline July 1, 2007 & 0 & 0 & $8.74 \%$ & $\$ 400,000$ & $12.0 \%$ & $4.5 \%$ \\
July 1, 2008 & 10 & 2.34 & $8.02 \%$ & $\$ 400,000$ & $11.0 \%$ & $3.5 \%$ \\
July 1, 2009 & 15 & 3.33 & $7.89 \%$ & $\$ 400,000$ & $11.0 \%$ & $2.5 \%$ \\
July 1, 2010 & 20 & 4.45 & $7.86 \%$ & $\$ 500,000$ & $10.5 \%$ & $2.5 \%$ \\
July 1, 2011 & 25 & 5.56 & $7.83 \%$ & $\$ 500,000$ & $10.0 \%$ & $2.5 \%$ \\
July 1, 2012 & 30 & 6.67 & $7.72 \%$ & $\$ 500,000$ & $10.0 \%$ & $2.5 \%$ \\
\hline \hline
\end{tabular}

* All non-carbon tax rate changes enacted on January 1st.

In column 2, \$/tonne refers to the price in Canadian dollars per carbon dioxide equivalent tonne. Column 3 displays the tax in cents per litre of unleaded liquid gasoline as calculated by the BC Ministry of Finance. The Personal Income Tax rates displayed in Column 4 are the average provincial tax rate for a household earning a nominal income of $\$ 100,000$ per year up to the point of the tax change (i.e., the tax rate is calculated such that all income is assumed to be earned instantaneously on July 1st). The provincial business limit in Column 5 is the level at which the high income corporate tax rate becomes effective. Column 6 presents the corporate tax rate for business profits that are greater than the provincial business limit, which is displayed in in Column 5. The Small Business Tax rate as shown in Column 7 applies to net income that is less than the small business limit (Column 5). 
Table 2: Least Squares Estimates of the Effect of Gasoline Prices and Carbon Taxes on Gasoline Consumption

\begin{tabular}{|c|c|c|c|c|}
\hline \multirow[b]{2}{*}{ Dependent Variable } & (1) & (2) & (3) & (4) \\
\hline & \multicolumn{2}{|c|}{$\begin{array}{l}\text { Monthly per Capita Gasoline } \\
\text { Consumption (litres) }\end{array}$} & \multicolumn{2}{|c|}{$\begin{array}{c}\text { Annual per Capita Gasoline } \\
\text { Consumption (litres) }\end{array}$} \\
\hline \multirow[t]{2}{*}{ Market Price of Gasoline } & -0.0014 & & -0.0002 & \\
\hline & $(0.0014)$ & & $(0.0027)$ & \\
\hline \multirow[t]{2}{*}{ Market Price of Gasoline ${ }^{*} \mathrm{BC}$} & & $-0.0043^{* *}$ & & -0.0034 \\
\hline & & $(0.0013)$ & & $(0.0025)$ \\
\hline \multirow[t]{2}{*}{ Carbon Tax } & $-0.0457 * *$ & & $-0.0631 * *$ & \\
\hline & $(0.0106)$ & & $(0.0178)$ & \\
\hline \multirow[t]{2}{*}{ Carbon Tax*BC } & & $-0.0210^{* *}$ & & $-0.0320^{* *}$ \\
\hline & & $(0.0085)$ & & (0.0119) \\
\hline Provincial Fixed Effects & Yes & Yes & Yes & Yes \\
\hline Month-Year Fixed Effects & Yes & Yes & & \\
\hline Year Fixed Effects & & & Yes & Yes \\
\hline Specification & log-linear & log-linear & log-linear & log-linear \\
\hline Observations & 2580 & 2580 & 216 & 216 \\
\hline
\end{tabular}

** - significant at a $1 \%$ level; * - significant at a $5 \%$ level

Table 2 reports the least squares estimates of the percent change in the per capita number of litres gasoline consumed that results from a corresponding one cent increase in the market price of gasoline and the carbon tax. All models include provincial and time fixed effects (either year or year-month) and the values in parentheses are the heteroskedasticity and autocorrelation consistent standard errors. (1) and (3) report national coefficients for the market price of gasoline and the carbon tax. (2) and (4) report the interactions for the province of British Columbia only. 
Table 3: Saliency of the Carbon Tax Relative to Market-Driven Price Changes: 95\% Confidence Intervals for Least Squares Models

Table 3: Saliency of the Carbon Tax Relative to Market-Driven Price Changes. $95 \%$ Confidence Intervals for Least Squares Models

(1)

Monthly per Capita Gasoline Consumption

(litres)

\begin{tabular}{|c|c|c|c|c|c|c|c|}
\hline Low & High & Low & High & Low & High & Low & High \\
\hline \multicolumn{2}{|c|}{ No } & \multicolumn{2}{|c|}{ No } & \multicolumn{2}{|c|}{ Yes } & \multicolumn{2}{|c|}{ Yes } \\
\hline \multirow[t]{2}{*}{-0.0024} & -0.0004 & & & -0.0080 & 0.0075 & & \\
\hline & & -0.0033 & -0.0005 & & & -0.0114 & 0.0047 \\
\hline \multirow[t]{2}{*}{-0.0538} & -0.0376 & & & -0.1236 & -0.0027 & & \\
\hline & & -0.0297 & -0.0123 & & & -0.0964 & 0.0325 \\
\hline
\end{tabular}

Overlapping Confidence Intervals

Market Price of Gasoline

Market Price of Gasoline*BC

Carbon Tax

Carbon $\operatorname{Tax} * \mathrm{BC}$

(3)

(4)

Annual per Capita Gasoline Consumption

(litres)
Estimated percent reduction in per capita gasoline consumption caused by a 5 cent increase in the:

Market Price of Gasoline

$0.7 \%$

$2.2 \%$

$10.6 \%$

$0.1 \%$

$32.6 \%$

$1.7 \%$

$16.3 \%$

Ratio of the demand response to the carbon tax relative to an equivalent change in market prices at $\$ 25$ per $t C O{ }_{2}$ e:

33.4

4.9

325.6

9.5

Table 3 reports the 95\% confidence intervals for the coefficients presented in Table 2. Model indicies correspond exactly with Table 2. Confidence intervals are calculated using estimated heteroskedasticity and autocorrelation consistent variance-covariance matrices. In (1) and (2), using the monthly data, the confidence intervals for the market price of gasoline and carbon tax coefficients do not overlap indicating that the hypothesis of an identical behavioural response must be rejected. (3) and (4) display overlapping confidence intervals implying that we cannot reject the hypothesis of equal coefficients. Also reported are the estimated percent reductions in per capita litres of gasoline consumed that would occur with a five cent increase in the market price and carbon tax respectively. Finally, the relative influence of the carbon tax to market-induced price changes is calculated. 
Table 4: Instrumental Variable Estimates for the Effect of Gasoline Prices and Carbon Taxes on Gasoline Consumption

\begin{tabular}{|c|c|c|c|c|}
\hline Dependent Variable & $\begin{array}{l}\text { Monthly per Capita Gasoline } \\
\text { Consumption (litres) }\end{array}$ & $\begin{array}{l}\text { Annual per Capita Gasoline } \\
\text { Consumption (litres) }\end{array}$ & $\begin{array}{l}\text { Annual per Capita Gasoline } \\
\text { Consumption (litres) }\end{array}$ & $\begin{array}{l}\text { Annual per Capita Gasoline } \\
\text { Consumption (litres) }\end{array}$ \\
\hline \multirow[t]{2}{*}{ Market Price of Gasoline* $\mathrm{BC}$} & $-0.0057^{* *}$ & -0.0013 & -0.0036 & $-0.0015^{*}$ \\
\hline & $(0.0012)$ & $(0.0023)$ & $(0.0020)$ & $(0.0007)$ \\
\hline \multirow[t]{2}{*}{ Carbon Tax*BC } & -0.0134 & -0.0361 & -0.0356 & $-0.0278^{* *}$ \\
\hline & $(0.0168)$ & $(0.0185)$ & $(0.0214)$ & $(0.0078)$ \\
\hline Provincial Fixed Effects & Yes & Yes & Yes & Yes \\
\hline Month-Year Fixed Effects & Yes & & & \\
\hline Year Fixed Effects & & Yes & Yes & Yes \\
\hline Specification & log-linear & log-linear & log-linear & log-linear \\
\hline Potentially Endogenous & Market Price of Gasoline*BC & Market Price of Gasoline*BC & & Market Price of Gasoline ${ }^{*} \mathrm{BC}$ \\
\hline \multirow[t]{3}{*}{ Variable } & & & Carbon Tax*BC & Carbon Tax*BC \\
\hline & Provincial Gasoline Excise & Provincial Gasoline Excise & & Provincial Gasoline Excise \\
\hline & Taxes & Taxes & & Taxes \\
\hline \multirow[t]{2}{*}{ Instruments } & & & $\begin{array}{c}\text { Provincial Personal Income } \\
\text { Tax Revenues }\end{array}$ & $\begin{array}{c}\text { Provincial Personal Income } \\
\text { Tax Revenues }\end{array}$ \\
\hline & & & $\begin{array}{c}\text { Provincial Corporate Income } \\
\text { Tax Revenues }\end{array}$ & $\begin{array}{c}\text { Provincial Corporate Income } \\
\text { Tax Revenues }\end{array}$ \\
\hline \multicolumn{5}{|c|}{ F-statistic for Excluded Instruments ${ }^{(a)}$} \\
\hline Excise Taxes & 566.25 & 29.33 & & 15.95 \\
\hline PIT and CIT & & & 19.23 & 6.55 \\
\hline Wu-Hausman Test & 1.26 & 0.36 & 0.05 & 142.31 \\
\hline (p-value) & $(0.26)$ & $(0.55)$ & $(0.82)$ & $(0.00)$ \\
\hline Sargan Test & & & 0.16 & 26.11 \\
\hline (p-value) & & & (0.69) & $(0.00)$ \\
\hline Observations & 2580 & 216 & 216 & 216 \\
\hline
\end{tabular}

** - significant at a $1 \%$ level; * - significant at a $5 \%$ level

(a) - The values reported in (4) are the Angrist-Pischke multivariate F-statistics (Angrist and Pischke, 2009).

Table 4 displays the instrumental variable estimates for four models. In (1), the dependent variable is monthly per capita gasoline consumption. (2), (3) and (4) have annual per capita gasoline consumption as the dependent variable. For (1) and (2), inflation-adjusted provincial excise taxes are used as instruments. (3) intruments the carbon tax with the log of provincial personal and corporate income tax. (4) considers both market price of gasoline and the carbon tax as potentially endogeneous and uses the provicial excise tax and personal and corporate income taxes as instruments. Values in parentheses are heteroskedasticity and autocorrelation corrected standard errors. Also reported are the F-statistics for the excluded instruments, the Wu-Hausman test for endogeneity and the Sargan test of the overidentifying restrictions. 
Table 5: Saliency of the Carbon Tax Relative to Market-Driven Price Changes: 95\% Confidence Intervals for Instrumental Variables Models

(1)

(2)

(3)

(4)

Dependent Variable

Monthly per Capita
Gasoline

Consumption (litres)

\begin{tabular}{|c|c|c|c|c|c|c|c|c|}
\hline & Low & High & Low & High & Low & High & Low & High \\
\hline Overlapping Confidence Intervals & \multicolumn{2}{|c|}{ Yes } & \multicolumn{2}{|c|}{ Yes } & \multicolumn{2}{|c|}{ Yes } & \multicolumn{2}{|c|}{ No } \\
\hline Market Price of Gasoline ${ }^{*} \mathrm{BC}$ & -0.0081 & -0.0032 & -0.0058 & 0.0032 & -0.0075 & 0.0003 & -0.0028 & -0.0001 \\
\hline Carbon Tax*BC & -0.0414 & 0.0195 & -0.0724 & 0.0003 & -0.0774 & 0.0063 & -0.0431 & -0.0125 \\
\hline
\end{tabular}

Estimated percent reduction in per capita gasoline consumption caused by a 5 cent increase in the:

\begin{tabular}{|c|c|c|c|c|}
\hline Market Price of Gasoline & $2.9 \%$ & $0.7 \%$ & $1.8 \%$ & $0.8 \%$ \\
\hline Carbon Tax & $6.7 \%$ & $18.4 \%$ & $18.1 \%$ & $14.1 \%$ \\
\hline
\end{tabular}

Ratio of the demand response to the carbon tax relative to an equivalent change in market prices at $\$ 25$ per tCO ${ }_{2}$ :

Table 5 reports the $95 \%$ confidence intervals for the coefficients presented in Table 4. Confidence intervals are calculated using heteroskedasticity and autocorrelation consistent variance-covariance matrices. Model indices correspond to the models in Table 4. (1) is for monthly data where gasoline prices are instrumented with excise taxes. (2), (3) and (4) use annual data where gasoline prices are instrumented with excise taxes and the carbon tax is instrumented with gross provincial personal and corporate income tax revenue. Overlapping confidence intervals indicates that we cannot reject the null hypothesis of a differential behavour response for market prices relative to the carbon tax. Also reported are the estimated percent reductions in per capita litres of gasoline consumed that would occur with a 5 cent increase in the market price and carbon tax respectively. Finally, the relative influence of the carbon tax to market-induced price changes is calculated. 
Table 6: Effect of Gasoline Prices and Carbon Taxes on Gasoline Consumption: Robustness Checks

\begin{tabular}{|c|c|c|c|c|c|}
\hline & (1) & (2) & (3) & (4) & (5) \\
\hline Dependent Variable & $\begin{array}{l}\text { Monthly per Capita } \\
\text { Gasoline } \\
\text { Consumption (litres) }\end{array}$ & $\begin{array}{c}\text { Annual per Capita } \\
\text { Gasoline } \\
\text { Consumption (litres) }\end{array}$ & $\begin{array}{c}\text { Monthly per Capita } \\
\text { Gasoline } \\
\text { Consumption (litres) }\end{array}$ & $\begin{array}{c}\text { Annual per Capita } \\
\text { Gasoline } \\
\text { Consumption (litres) }\end{array}$ & $\begin{array}{l}\text { Monthly per Capita } \\
\text { Gasoline } \\
\text { Consumption (litres) }\end{array}$ \\
\hline Market Price of Gasoline*BC & $\begin{array}{c}-0.0042^{* *} \\
(0.0005)\end{array}$ & $\begin{array}{l}-0.0034 \\
(0.0019)\end{array}$ & $\begin{array}{c}-0.0017^{* *} \\
(0.0004)\end{array}$ & $\begin{array}{l}-0.0017 \\
(0.0016)\end{array}$ & $\begin{array}{c}-0.0040 * * \\
(0.0013)\end{array}$ \\
\hline Carbon Tax*BC & $\begin{array}{c}-0.0148 * * \\
(0.0054)\end{array}$ & $\begin{array}{l}-0.0209 \\
(0.0191)\end{array}$ & $\begin{array}{c}-0.0216 * * \\
(0.0004)\end{array}$ & $\begin{array}{l}-0.0165 \\
(0.0195)\end{array}$ & $\begin{array}{c}-0.0163 * * \\
(0.0063)\end{array}$ \\
\hline Income $e^{(a)}$ & $\begin{array}{l}0.0217^{* *} \\
(0.0023)\end{array}$ & $\begin{array}{l}0.0178 * * \\
(0.0056)\end{array}$ & $\begin{array}{c}0.0063 \\
(0.0066)\end{array}$ & $\begin{array}{c}0.0043 \\
(0.0047)\end{array}$ & \\
\hline Provincial Fixed Effects & Yes & Yes & Yes & Yes & Yes \\
\hline Month-Year Fixed Effects & Yes & & Yes & & Yes \\
\hline Year Fixed Effects & & Yes & & Yes & \\
\hline Sample Restriction & None & None & None & None & Limit to $2007-2011$ \\
\hline Specification & log-linear & log-linear & log-linear & log-linear & log-linear \\
\hline Transformation of Variables & None & None & First Differences & First Differences & None \\
\hline Observations & 2460 & 205 & 2460 & 205 & 600 \\
\hline & (6) & (7) & (8) & (9) & (10) \\
\hline Dependent Variable & $\begin{array}{c}\text { Monthly per Capita } \\
\text { Gasoline } \\
\text { Consumption (litres) }\end{array}$ & $\begin{array}{c}\text { Monthly per Capita } \\
\text { Gasoline } \\
\text { Consumption (litres) }\end{array}$ & $\begin{array}{c}\text { Monthly per Capita } \\
\text { Gasoline } \\
\text { Consumption (litres) }\end{array}$ & $\begin{array}{c}\text { Annual per Capita } \\
\text { Gasoline } \\
\text { Consumption (litres) }\end{array}$ & $\begin{array}{c}\text { Annual per Capita } \\
\text { Gasoline } \\
\text { Consumption (litres) }\end{array}$ \\
\hline Market Price of Gasoline ${ }^{*} \mathrm{BC}$ & $\begin{array}{c}-0.0043^{* *} \\
(0.0006)\end{array}$ & $\begin{array}{l}-0.0042^{* *} \\
(0.0006)\end{array}$ & & $\begin{array}{l}-0.0027 \\
(0.0040)\end{array}$ & $\begin{array}{l}-0.0018 \\
(0.0039)\end{array}$ \\
\hline Carbon Tax*BC & $\begin{array}{c}-0.0208 * * \\
(0.0048)\end{array}$ & $\begin{array}{c}-0.0241^{* *} \\
(0.0053)\end{array}$ & & $\begin{array}{l}-0.0334 \\
(0.0317)\end{array}$ & $\begin{array}{l}-0.0276 \\
(0.0314)\end{array}$ \\
\hline Market Price of Gasoline & & & $\begin{array}{l}-0.0002 \\
(0.0002)\end{array}$ & & \\
\hline Carbon Tax & & & $\begin{array}{c}-0.0456^{* *} \\
(0.0021)\end{array}$ & & \\
\hline \%age small cars out of car sales & & & & $\begin{array}{c}-1.1716 * * \\
(0.3284)\end{array}$ & \\
\hline \%age small cars out of all vehicle sales & & & & & $\begin{array}{c}-1.1611 * * \\
(0.2828)\end{array}$ \\
\hline Provincial Fixed Effects & Yes & Yes & Yes & Yes & Yes \\
\hline Month-Year Fixed Effects & Yes & Yes & & & \\
\hline Year Fixed Effects & & & & Yes & Yes \\
\hline Province*Month Fixed Effects & & & Yes & & \\
\hline Trend & & & Yes & & \\
\hline $\begin{array}{l}\text { Sample Restriction } \\
\text { Specification }\end{array}$ & $\begin{array}{l}\text { Drop June-July } \\
\text { log-linear }\end{array}$ & $\begin{array}{l}\text { Drop May-August } \\
\text { log-linear }\end{array}$ & $\begin{array}{c}\text { None } \\
\text { log-linear }\end{array}$ & $\begin{array}{c}\text { None } \\
\text { log-linear }\end{array}$ & $\begin{array}{c}\text { None } \\
\text { log-linear }\end{array}$ \\
\hline Observations & 2150 & 1730 & 2580 & 216 & 216 \\
\hline
\end{tabular}

** - significant at a $1 \%$ level; * - significant at a $5 \%$ level

(a)- Income is scaled by 100 for the monthly models (1) and (3) and by 1000 for the annual models (2) and (4).

Table 6 presents a series of robustness checks. (1) and (2) include after-tax income into the monthly and annual models. (3) and (4) use firstdifferenced data for the monthly and annual models. A shorter time period, from 2007-2011, is estimated in (5) to ensure that the results are robust to potential structural changes. (6) and (7) drop June and July and May through August (resp.) to ensure that the coefficients on the market price of gasoline and carbon tax are not driven by announcement or storage effects. Provincial dummies are interacted with month dummies and a time trend is included in (8). (9) and (10) include the share of small and compact cars sold as a percentage of all cars and vehicles sold, respectively, in each province. Value in parentheses are heteroskedasticity and autocorrelation robust standard errors. 
Table A1: Summary Statistics for the Monthly Gasoline Consumption and the Market Price of

\begin{tabular}{lcccccccc}
\hline \hline & \multicolumn{3}{c}{ Per Capita Gasoline Consumption } & \multicolumn{3}{c}{ Price of Gasoline } \\
\cline { 2 - 9 } & Mean & StdDev & Min & Max & Mean & StdDev & Min & Max \\
\hline Alberta & 177.79 & 15.50 & 142.13 & 260.84 & 68.52 & 11.95 & 49.51 & 107.22 \\
British Columbia & 114.94 & 11.63 & 88.76 & 146.70 & 78.28 & 18.83 & 48.02 & 130.47 \\
Manitoba & 138.70 & 10.98 & 105.98 & 171.55 & 72.89 & 14.07 & 50.92 & 117.91 \\
New Brunswick & 143.99 & 17.34 & 106.81 & 203.15 & 77.33 & 14.28 & 54.99 & 119.41 \\
Newfoundland & 119.31 & 18.61 & 83.63 & 195.84 & 82.32 & 13.93 & 60.94 & 126.23 \\
Nova Scotia & 133.36 & 13.60 & 98.24 & 167.71 & 77.77 & 14.87 & 54.19 & 120.71 \\
Ontario & 128.47 & 7.78 & 109.88 & 149.87 & 72.84 & 13.82 & 53.35 & 114.68 \\
Prince Edward Island & 164.32 & 25.73 & 115.86 & 235.60 & 75.68 & 12.66 & 52.98 & 115.00 \\
Quebec & 112.89 & 7.70 & 89.36 & 140.64 & 79.19 & 14.84 & 56.55 & 126.40 \\
Saskatchewan & 205.48 & 35.92 & 132.73 & 303.03 & 75.80 & 13.42 & 49.25 & 117.26 \\
\hline \hline
\end{tabular}

Gasoline consumption is in litres. Prices are inflation-adjsuted and tax-inclusive. 